\title{
GLOBAL REGULATORY ASPECTS OF WOUND CARE AND BURN DRESSINGS
}

\author{
VIBHUYADAV ${ }^{1}$, PARIKSHITBANSAL ${ }^{2}$, AMITMITTAL ${ }^{1 *}$, SACHIN KUMAR SINGH ${ }^{1}$
}

${ }^{1}$ School of Pharmaceutical Sciences, Lovely Professional University, Jalandhar, Punjab, India. ${ }^{2}$ Ex-Faculty (IPR), NIPER, Mohali, Haryana, India. Email: amit.13145@Ipu.co.in

Received: 18 April 2018, Revised and Accepted: 04 June 2018

ABSTRACT

Objective: The objective of the study was to present an overview of regulatory requirements for wound and burn care dressings.

Methods: A total of 80 research and review articles including regulatory guidelines to control the marketing of wound and burn care dressings recommended by international regulatory agencies were reviewed.

Results: A wide range of dressings, as a new target of the healing process, have been developed due to continued growth and innovations in the field. Ideal dressings should be safe and achieve healing at a reasonable cost with minimum inconvenience to patients. It is mandatory that manufacture and sale of such dressings are approved by the relevant health authority of each country. This article provides manufacturers with an overview regarding regulatory approval procedures for marketing such dressings in different countries and addresses the gaps and challenges in the existing guidelines aimed at maintaining product quality. It provides a comparative analysis of the differences in regulatory requirements and highlights that ongoing discussions and appropriate actions are required to support the continuous development of these dressings. Most countries have their own regulatory guidelines, and the approval processes differ according to the country. Quality parameters concerning the type of material, pore size, sterilization methods, shape and size, and labeling are not discussed in guidelines; therefore, innovators and manufacturers are facing tough challenges to showcase their products in the market, and this further leads to either lack of market availability or high cost of such dressings.

Conclusion: Development of common quality guidelines is essential for market availability of low-cost, high-quality dressings.

Key words: Surgical dressings, Wound dressings, Regulated market, Semi-regulated markets, Approval process, Burn dressings.

(C) 2018 The Authors. Published by Innovare Academic Sciences Pvt Ltd. This is an open access article under the CC BY license (http://creativecommons. org/licenses/by/4. 0/) DOI: http://dx.doi.org/10.22159/ajpcr.2018.v11i7.26772

\section{INTRODUCTION}

Burn and wound injury is a prevalent and burdensome critical care issue. Furthermore, burn wounds are complex and present unique challenges that require specialized care to protect from microbial infection [1]. According to the World Health Organization (WHO), more than 300,000 deaths occur each year as a consequence of fire-induced burns [2]. Approximately 3.5 million burn patients globally enter the outpatient health service system and receive some level of medical attention. The burden of such injuries generally falls on poor patients as they cannot afford costly treatments, and a primary contributing factor that leads to infection and finally to death in this population is poor hygiene. Burn injury management is challenging, due to significant fluid loss, tissue damage, and deep wounds, thus contributing to death $[2,3]$. At present, various novel dressings are being developed worldwide; however, due to lack of clear understanding of approval procedures, they are not accessible to patients.

This study provides details regarding the regulatory status, including approval procedures, and regulatory hurdles for new innovations that are not yet available for patient use. Decisions that are made regarding regulatory approval for a specific product lie within the regulatory authority of the country in which the product is to be marketed. A comparative study detailing regulatory requirements, approval timelines, and required approval fees in different countries has been conducted [2,3]. It has been identified that there is an utmost requirement for common regulatory guidelines; especially quality guidelines that may help attract more innovators and manufacturers to produce such dressings.

Globally, over 100 million surgical incisions occurring per year require wound management, indicating a $3.1 \%$ compound annual growth rate (CAGR) [4]. The prevalence of various wound types is shown in Table 1 [4].

A wound is generally defined as a disruption in the continuity of the epithelial lining of the skin or mucosa [5]. There are many types of wounds with multiple causes for their occurrence. The healing process is very complex; to prevent from microbial infection and to facilitate the body's natural healing mechanisms, an optimal healing environment and an appropriate wound dressing are often required [6].

There is a wide range of advanced and traditional wound care and burn dressings available, and the global wound dressing market is expected to expand at a CAGR of $4.5 \%$ during the forecast period from 2014 to 2020. In 2013, the global wound dressing market was estimated to be greater than US $\$ 7.5$ billion, and by 2020 it is projected to be more than US $\$ 10.1$ billion [7]. Standard wound dressings include wound closure products (gauze tapes, sponges, surgical cotton swabs, and others), basic wound care products, and antiseptic dressings. More advanced wound dressings include emerging and existing products such as films, foam dressings, Hydrofiber dressings, hydrocolloids, hydrogels, collagen dressings, and alginates [8,9]. Various types of advanced wound care dressings currently available are shown in Table 2, and research and development are ongoing.

Simple wound care or surgical dressings currently available cannot be used to cover the entire burned skin surface area of patients. Therefore, to overcome the challenges associated with the management of wound care and burn injuries, clinical trials are underway to evaluate novel products, such as Beta foam and Allevyn Silver dressing for burn wounds and acute burns, Inerpan for the treatment of partial-thickness burns, and honey for wound management $[22,23]$. 
Table 1: Estimated prevalence and growth rate of various wound types, 2011-2020 [4]

\begin{tabular}{lll}
\hline Wound type & $\begin{array}{l}\text { Worldwide } \\
\text { prevalence (thousands) }\end{array}$ & $\begin{array}{l}\text { CAGR } \\
\mathbf{( 2 0 1 2 - 2 0 2 0 )}(\%)\end{array}$ \\
\hline Surgical wounds & 114271 & 3.6 \\
Traumatic & 1627 & 1.7 \\
wounds & & \\
Lacerations & 20645 & 1.2 \\
Burn wounds & 10221 & 1.2 \\
Chronic wounds & 40400 & 7.6 \\
Carcinoma & 618 & 3.0 \\
Melanoma & 103 & 3.2 \\
Skin cancer & 103 & 3.1 \\
\hline
\end{tabular}

CAGR: Compound annual growth rate
In general, wound care and burn dressings are classified on the basis of the risk associated with the wound and are categorized as medical devices [24]. They are classified as Class I-IV and, in some countries, they are classified as Class A-D. Class A or Class I wound dressings are generally associated with low-risk wounds, and a low regulatory standard is required for their approval [24]. General classification is shown in Table 3

In regulated markets (the USA, the European Union [EU], and Japan), wound dressings are classified as ClassA medical devices, for which no separate dossier submission is required, and maintenance of the safety and quality of the product is mainly the manufacturer's responsibility [25]. In emerging markets, they are classified as medical devices, although in some countries, proper classification and guidelines have not been established yet. These countries seek for

Table 2: Types of advanced wound care and burn dressings

\begin{tabular}{|c|c|c|c|c|}
\hline Type of dressing & $\begin{array}{l}\text { Examples/product brand } \\
\text { names }\end{array}$ & Components & Intended use & References \\
\hline \multicolumn{5}{|l|}{ Advanced wound dressings } \\
\hline Foam dressings & $\begin{array}{l}\text { Biatain, tegaderm, restore, } \\
\text { optifoam, mepilex, PolyMem, } \\
\text { Cura form (3M) }\end{array}$ & $\begin{array}{l}\text { Polymers, often } \\
\text { polyurethane }\end{array}$ & $\begin{array}{l}\text { For use beneath compression } \\
\text { stockings, for patients with } \\
\text { venous leg ulcers }\end{array}$ & {$[9-11]$} \\
\hline Hydrocolloid dressings & $\begin{array}{l}\text { Biopad, tegasorb, comfeel, } \\
\text { hydrocoll, varihesive E, } \\
\text { medihoney tube (Coloplast/ } \\
\text { Sween) }\end{array}$ & $\begin{array}{l}\text { Adhesive, absorbent, and } \\
\text { elastomeric components, } \\
\text { carboxymethyl cellulose }\end{array}$ & $\begin{array}{l}\text { Intended for use on } \\
\text { light-to-moderate exuding, } \\
\text { acute or chronic partial- or } \\
\text { full-thickness wounds }\end{array}$ & {$[9-11]$} \\
\hline Film dressings & $\begin{array}{l}\text { 3M Tegaderm, Pro-claude, } \\
\text { Polyskin II, ProCyte } \\
\text { film (proCyte) }\end{array}$ & $\begin{array}{l}\text { Single thin transparent } \\
\text { sheet of polyurethane } \\
\text { coated on one side with } \\
\text { an adhesive }\end{array}$ & $\begin{array}{l}\text { Superficial wounds with little } \\
\text { exudate, secondary dressing } \\
\text { to attach a primary absorbent } \\
\text { dressing }\end{array}$ & {$[9-11]$} \\
\hline Hydrogel & $\begin{array}{l}\text { Aquasite, ReliaMed, Anasept, } \\
\text { Flex derm, Nu-Gel (Dow Hickam, } \\
\text { Johnson \&Johnson) }\end{array}$ & $\begin{array}{l}\text { Three-dimensional } \\
\text { networks of cross-linked } \\
\text { hydrophilic polymers }\end{array}$ & $\begin{array}{l}\text { Used to retain the gel in shallow } \\
\text { wounds }\end{array}$ & [9-11] \\
\hline Collagen & $\begin{array}{l}\text { Prisma, Promogran, } \\
\text { Stimulen (Systagenix) }\end{array}$ & Collagen & $\begin{array}{l}\text { Wounds with minimal, moderate, } \\
\text { or heavy drainage }\end{array}$ & {$[9,10,12]$} \\
\hline \multicolumn{5}{|l|}{$\begin{array}{l}\text { Therapy device } \\
\text { NPWT }\end{array}$} \\
\hline Conventional NPWT & $\begin{array}{l}\text { VAC therapy, vista } \\
\text { versatile (Boehringer wound } \\
\text { systems LLC), Engenex } ®\end{array}$ & $\begin{array}{l}\text { Consist of three } \\
\text { components: Porous } \\
\text { non adhesive packing } \\
\text { material, occlusive seal, } \\
\text { airtight container system }\end{array}$ & $\begin{array}{l}\text { Potential to accelerate healing } \\
\text { process }\end{array}$ & {$[9-13,15,16]$} \\
\hline $\begin{array}{l}\text { Oxygen and hyperbaric } \\
\text { oxygen equipment }\end{array}$ & $\begin{array}{l}\text { OxyHeal (OxyHeal Health } \\
\text { Group) }\end{array}$ & $\begin{array}{l}\text { Hydrogel sheet } \\
\text { containing glucose and } \\
\text { an enzyme oxidase }\end{array}$ & Stimulates wound healing & {$[9,12,14]$} \\
\hline $\begin{array}{l}\text { Electrical stimulation } \\
\text { devices }\end{array}$ & POSIFECT (Biofisica LLC) & $\begin{array}{l}\text { Derived from two } 3-\mathrm{V} \\
\text { nominal lithium coin cell } \\
\text { batteries that deliver } \\
\text { electric current to the } \\
\text { wound bed }\end{array}$ & $\begin{array}{l}\text { Stimulates the wound healing } \\
\text { process }\end{array}$ & {$[9,14,17-19]$} \\
\hline $\begin{array}{l}\text { Active wound care device } \\
\text { Artificial skin and skin } \\
\text { substitutes } \\
\text { Surgical wound care }\end{array}$ & $\begin{array}{l}\text { Biobrane, TransCyte (Smith and } \\
\text { Nephew) }\end{array}$ & $\begin{array}{l}\text { Biosynthetic skin } \\
\text { substitute }\end{array}$ & $\begin{array}{l}\text { Provides protection from bacterial } \\
\text { influx and mechanical coverage }\end{array}$ & {$[12-14]$} \\
\hline Fibrin-based sealants & $\begin{array}{l}\text { Fibrin-coated wound } \\
\text { dressing }(3 \mathrm{M})\end{array}$ & $\begin{array}{l}\text { A fibrin-coated dressing } \\
\text { with a flexible film layer, } \\
\text { a pressure-sensitive } \\
\text { adhesive layer, and a } \\
\text { fibrin powder layer }\end{array}$ & $\begin{array}{l}\text { Used as a scaffold in tissue } \\
\text { regeneration strategies }\end{array}$ & {$[9,16-18]$} \\
\hline Collagen-based sealants & $\begin{array}{l}\text { Regranex, Autogel, Multidex } \\
\text { gel (Smith and Nephew) }\end{array}$ & $\begin{array}{l}\text { Comprised collagen or } \\
\text { hyaluronic acid }\end{array}$ & Stimulates wound healing & {$[9,12,14]$} \\
\hline Anti-infective dressings & $\begin{array}{l}\text { Silver dressing, Algidex, Aquacel } \\
\text { Ag (DeRoyal) }\end{array}$ & $\begin{array}{l}\text { Hybrid dressings that } \\
\text { provide healing advantage }\end{array}$ & Broad-spectrum activity & {$[9,12,19-21]$} \\
\hline
\end{tabular}

NPWT: Negative pressure wound therapy, VAC: Vacuum-assisted closure 
US and EU approval marks and do not ask for additional approval, if products have been previously approved in these countries [26-28].

\section{USA}

In the USA, surgical and wound care dressings are regulated by the Food and Drug Administration (USFDA) under the Medical Device Regulation Act and are classified as Class I and II [29]. In general, classification depends on the complexity and invasiveness of the dressings. Examples of dressings are detailed in Table 4.

For Class I dressings, separate regulatory approval is not required, unlike Class II dressings that require $510(\mathrm{k})$ approval. This approval process requires demonstration of "substantial equivalence" to a similar device marketed before 1976 and does not require any clinical research, for example, Oasis Wound Matrix, Prisma, and Medihoney [30,31].

Class III wound care dressings are considered to have the highest risk, for example, derma graft, designed to restore the dermal bed in diabetic foot ulcers, thereby improving the wound healing process and allowing patients' own epithelial cells to migrate to the wound and close it. Apligraf is a living cell-based product for chronic venous leg ulcers and diabetic foot ulcers. Apligraf is supplied as a living, bi-layered skin substitute. These are the only two wound care products approved by the FDA under Class III [32].

The well-defined approval procedure for wound care dressings in the US motivates researchers to present new and innovative products designed for clinical access and application.

\section{Approval procedure}

- Step 1 (identification of classification): According to USFDA medical device guidelines, surgical dressings are categorized as Class II medical devices.

- Step 2 (identification of predicate): Before registration, a check of predicate devices in the USFDA-provided database is required. Predicate devices are listed as similar medical devices prior approved by the USFDA through the $510(\mathrm{k})$-approval process. An exact classification of a product and all its requirements can be easily identified through this database.

- Step 3 (identification of pre-requisites and regulatory requirements): According to the USFDA guidelines, wound care dressings are categorized as Class II, for which no separate dossier submission is required. The product classification codes are used to determine whether any standards and/or guidance documents apply to the device. Before submitting the application, applicants are required to complete the following:

Table 3: General classification of wound dressings [24]

\begin{tabular}{|c|c|c|}
\hline Class & Risk level & Type of dressings \\
\hline A & Low & Wound dressing \\
\hline B & Low-moderate & Hydrogel dressings \\
\hline $\mathrm{C}$ & Moderate-high & Deep wound dressing \\
\hline D & High & $\begin{array}{l}\text { Medicated dressings, sterile dressings, } \\
\text { products containing biomaterials of } \\
\text { human origin }\end{array}$ \\
\hline
\end{tabular}

- Quality management system (QMS)

- Literature supporting substantial equivalence to the predicate

- Clinical data, if available (the USFDA may raise safety efficacy questions)

- $510(\mathrm{k})$ application form for USFDA notification.

- Step4 (Submission request to FDA): Following classification identification and before final submission, a request is made to the USFDA.

- Step 5 (FDA feedback): The FDA will review the classification of products and the similarity of claimed predicate devices.

- Step 6 (submission and review): Applicants then submit the application to the FDA and pay for the stated fee to have the submission reviewed. FDA will review the submission within 90 days and may request additional information, as appropriate. Successful applicants will be issued with a $510(\mathrm{k})$-clearance letter, along with a $510(\mathrm{k})$ number by FDA.

- Step 7 (issuance of a clearance letter): A clearance letter is required to market the product in the USA. A clearance letter is an FDA declaration that a product is substantially equivalent to a predicate device selected through the $510(\mathrm{k})$ process, which has previously been cleared by FDA for sale. The clearance letter should be uploaded onto the FDA website under "device listing and establishment registration system" using the FDA's unified registration listing system.

- Step 8 (renewal and validity): Once FDA issues a $510(\mathrm{k})$ approval, a number is assigned with an unlimited period of validity. However, it is mandatory to remain in compliance with the quality system and within all FDA regulations to continue the sale of the product in the USA. FDA may conduct random inspections of the manufacturing facility to ensure compliance with the quality systems regulation (21 code for federal regulations part 820.70). The full approval procedure EU is outlined in Fig. 1 [31].

The European Medicines Agency is the regulatory body for wound care and burn dressings within the Medical Devices Directive (MDD) 93/42/ EEC [29]. To commercialize wound care and burn dressings in the EU, a European Conformity (CE) Mark certificate is needed [33].

\section{Approval procedure}

- Step 1 (classification and applicable MDD directive) In accordance with the EU Directive93/42/EEC, wound dressings are categorized as Class I (non-sterile and non-measuring), or Class I (sterile and measuring).

- Step 2 (identification of regulatory requirements) Before submitting the application, compliance with the following regulatory requirements is needed:

- QMS in accordance with the 92/43/EEC

- Technical file in compliance with 92/43/EEC

- Safety tests in accordance with EU standards

- International Organization for Standardization (ISO) 13485

- Declaration of conformity.

- Step 3 (preparation of technical documents) Detailed information concerning the product is provided in this section, in accordance with the 94/42/EEC directive. Implementation of a QMS is required in accordance with Annexure-II of the Medical Device Directive and ISO 13485 standards. Manufacturers are

Table 4: List of dressings and associated level of risk [30]

\begin{tabular}{lllll}
\hline Type & Examples & Level of risk & FDA classification & Regulatory requirements \\
\hline Fabric dressings & $\begin{array}{l}\text { Hydrophilic wound dressings, } \\
\text { occlusive wound dressings, } \\
\text { hydrogel wound dressings }\end{array}$ & Low risk & Class I & $\begin{array}{l}\text { Approval not required; the FDA only needs } \\
\text { to be informed before marketing. It is } \\
\text { the responsibility of the manufacturer to } \\
\text { maintain the safety and quality of the product }\end{array}$ \\
$\begin{array}{l}\text { Advanced } \\
\begin{array}{l}\text { Mound care } \\
\text { dressings }\end{array}\end{array}$ & $\begin{array}{l}\text { Medihoney, Prisma, Oasis wound } \\
\text { matrix }\end{array}$ & $\begin{array}{l}\text { Intermediate } \\
\text { risk }\end{array}$ & Class II & $510(\mathrm{k})$ approval is required \\
\hline
\end{tabular}




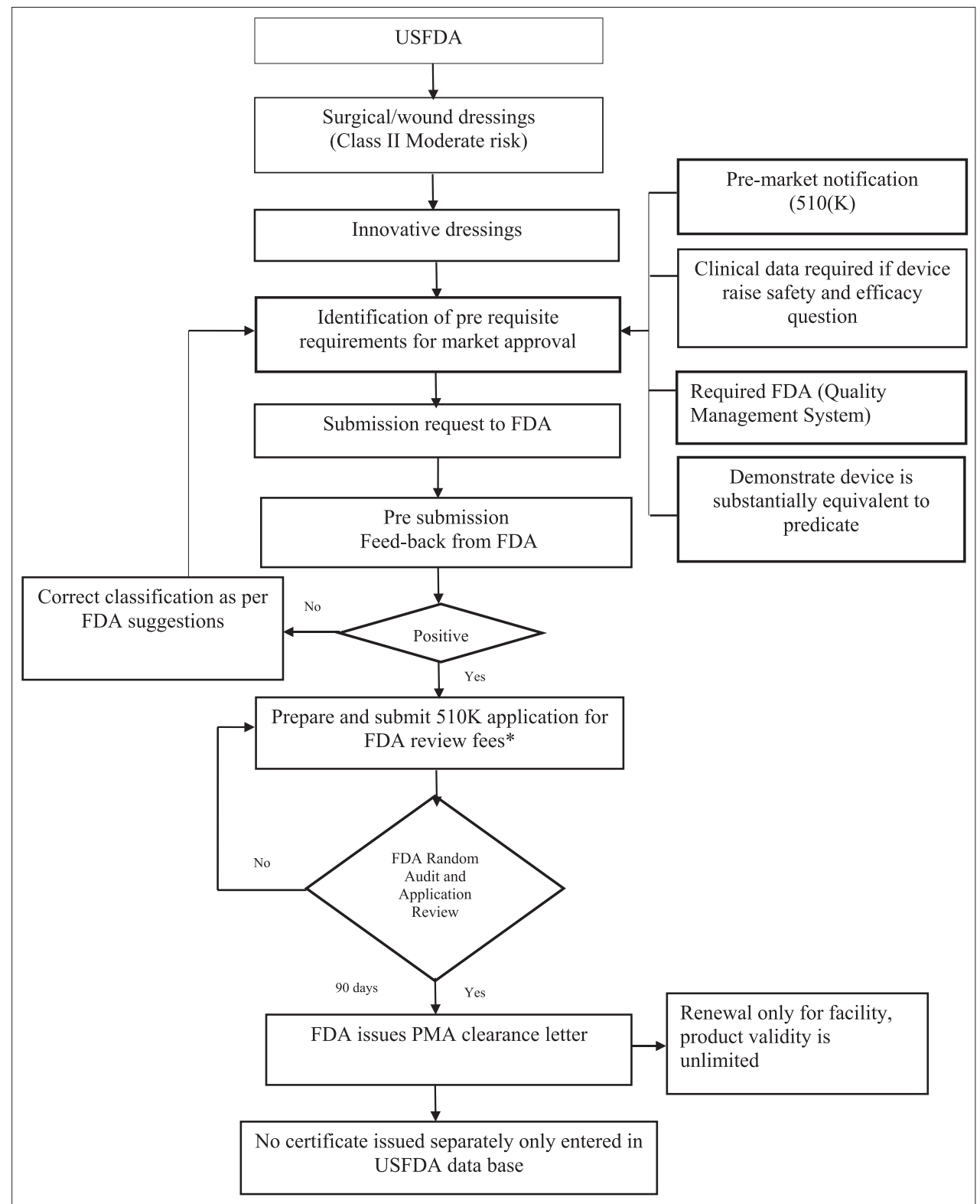

Fig. 1: Decision tree for the approval process in the United States [29-32]. *Application fees (\$5018) are revised annually. Updated information concerning fees can be obtained at: Support@fdaagents.com. PMA: Pre-market approval application, FDA: Food and Drug Administration

required to submit a declaration of conformity, which is a legally binding document stating that the device complies with the applicable directive.

- Step 4 (submission of application to the Ministry of Health [MOH]) The application is submitted to the MOH along with the specified fee.

- Step 5 (application review)

The QMS/technical dossier is reviewed by the regulatory body, and an audit is scheduled.

- Step 6 (audit by the notified body)

If a wound care dressing is categorized as Class I (sterile and nonmeasuring), the QMS and technical file or the design dossier should be audited by the notified body. After a successful audit, the European CE marking certificate for the device and an ISO 13485 certificate for the facility are issued.

- Step 7 (certification/validity and renewal)

CE marking certificates are typically valid for 3 years. ISO 13485 certification must be renewed every year. Every year, the EU notified body will check compliance with 92/43/EEC. The full approval procedure is outlined in Fig. 2 [33-38].

\section{Japan}

The $\mathrm{MOH}$, Labor, and Welfare (MHLW) in Japan regulates wound care dressings under the medical devices category $[29,39]$. The Japanese Pharmaceutical Affairs Law (PAL) defines wound care dressings as medical devices that are intended for use in the diagnosis, treatment, or prevention of disease in humans or animals, or intended to affect the structure or functions of the bodies of humans or animals. To engage in marketing, wound care and burn dressings manufacturers should obtain marketing business licenses (Marketing Authorization Holder [MAH]). The approval process is overseen by the Pharmaceuticals and Medical Devices Agency (PMDA), a division of the MHLW. To market surgical or wound dressings in Japan, manufacturers/marketing holders must register the device through the following procedures:

- Step 1 (classification determination): According to the Japanese PAL and the Japanese Medical Device Nomenclature codes, wound care dressings and surgical dressings are categorized as Class I and as general medicine Class I medical devices.

- Step 2 (identification of regulatory requirements): Before submitting an application for marketing approval, manufacturers should prepare 


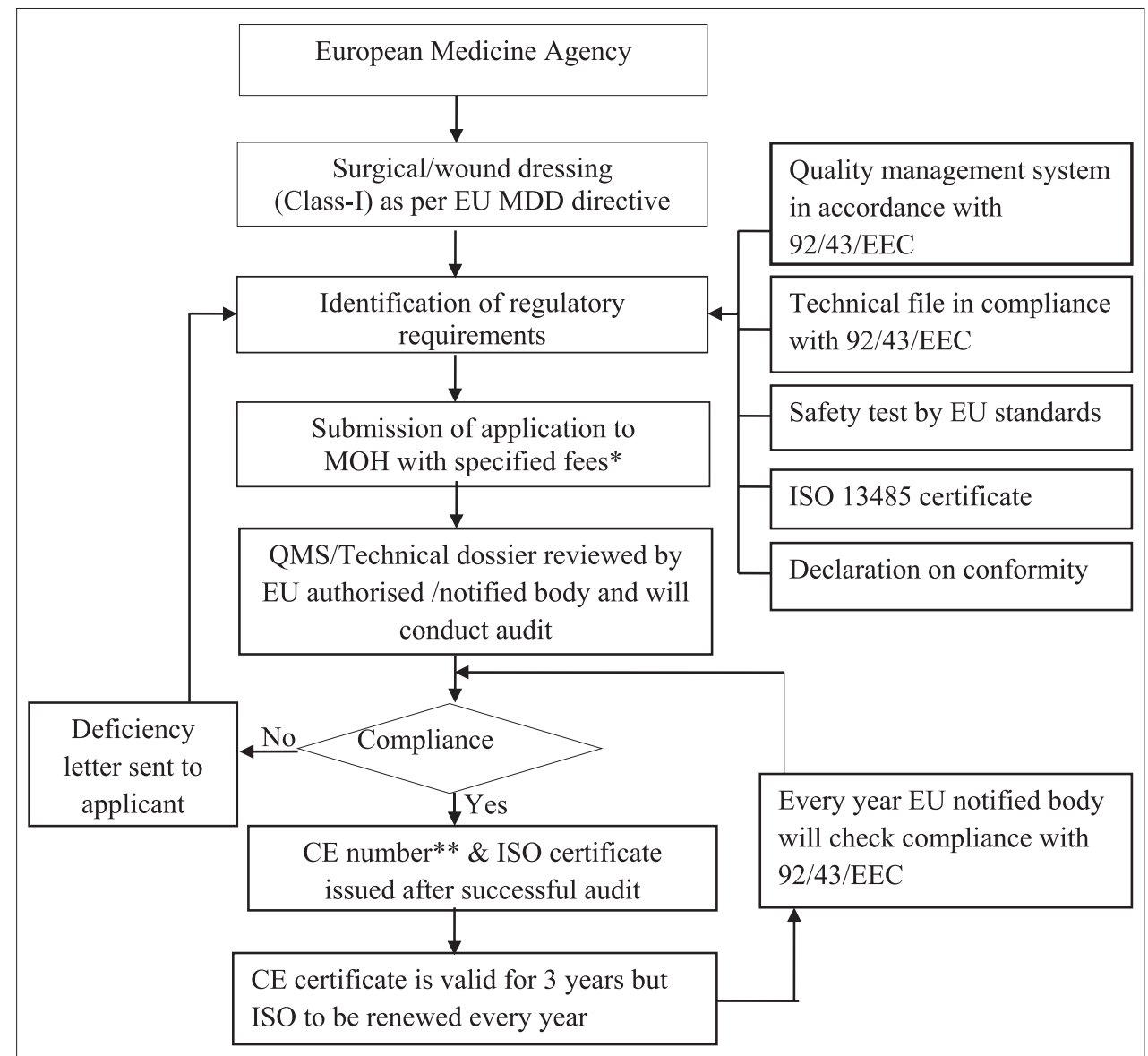

Fig. 2: Decision tree for the European Union approval procedure. *Fees vary in 30 member states. More details available on: http://www. mhra.com/cost-and-fees-for-the-registration-with-MHRA.html ${ }^{* *}$ No separate regulatory approval required. Manufacturers can use the CE mark if their product fully complies with the EU directive. QMS: Quality management system, MDD; Medical device directive

the following documents and product information. All documents must be written in Japanese.

Information required for surgical dressings as Class I medical devices in Japan:

- QMS in compliance with Japanese Ordinance 169

- Self-declaration

- Completed pre-market application form

- Category or classification of the product

- Generic name, if any

- Proprietary name

- Intended use

- Shape and structure including the following items, where applicable: Color photo, size and weight, components and accessories, electrical rating, and block diagram.

- Raw materials: Quantity (weight and percentage), materials specification (chemical and/or physical characteristics).

- Product specifications (defined according to each product), for example, appearance and/or physical characteristics.

- Directions for use

- Manufacturer(s) and manufacturing method

- Storage conditions and shelf life

- Notes on the following items, where applicable: Single-use or not, and usage of components of other medical devices

- Package inserts (directions for use) draft

- Color photo (digital image).

- Step 3 (submit pre-market application): Submission of the application for foreign manufacturer accreditation (Form No. 18) and implementation of the QMS.
- $\quad$ Step 4 (conformity assessment): After submission of all documents and required information, a conformity assessment is undertaken by the regulatory body.

- Step 5 (certification or renewal and validity): After 1 month, a decision regarding approval/rejection is reached by the PMDA. No separate certificate is issued for Class I devices, and approval is valid until there is any change in the QMS. The full approval procedure is outlined in Fig. 3 [39].

Canada

Wound care and surgical dressings are classified as medical devices and are defined in the Food and drugs act, which "covers a wide range of health or medical instruments used in the treatment, mitigation, diagnosis, or prevention of a disease or abnormal physical condition." The approval process is regulated by the medical devices regulations (MDR) and wound care dressing classifications depend on their intended use or the risk associated with the use of dressings. If a product is classified as a Class I device, a medical device license is not required. The rules governing the classification of medical devices are outlined in schedule 1 (parts 1 and 2) of the MDR. The approval procedure is detailed in Fig. 4 [40,41].

- Step 1 (determining classification): In accordance with the Canadian MDR schedule 1, wound care and surgical dressings are categorized as Class I medical devices.

- Step 2 (identification of regulatory requirements): Before application for market approval, manufacturers should make available the documents listed below:

- Medical device establishment license with a list of manufacturers (MDEL) 


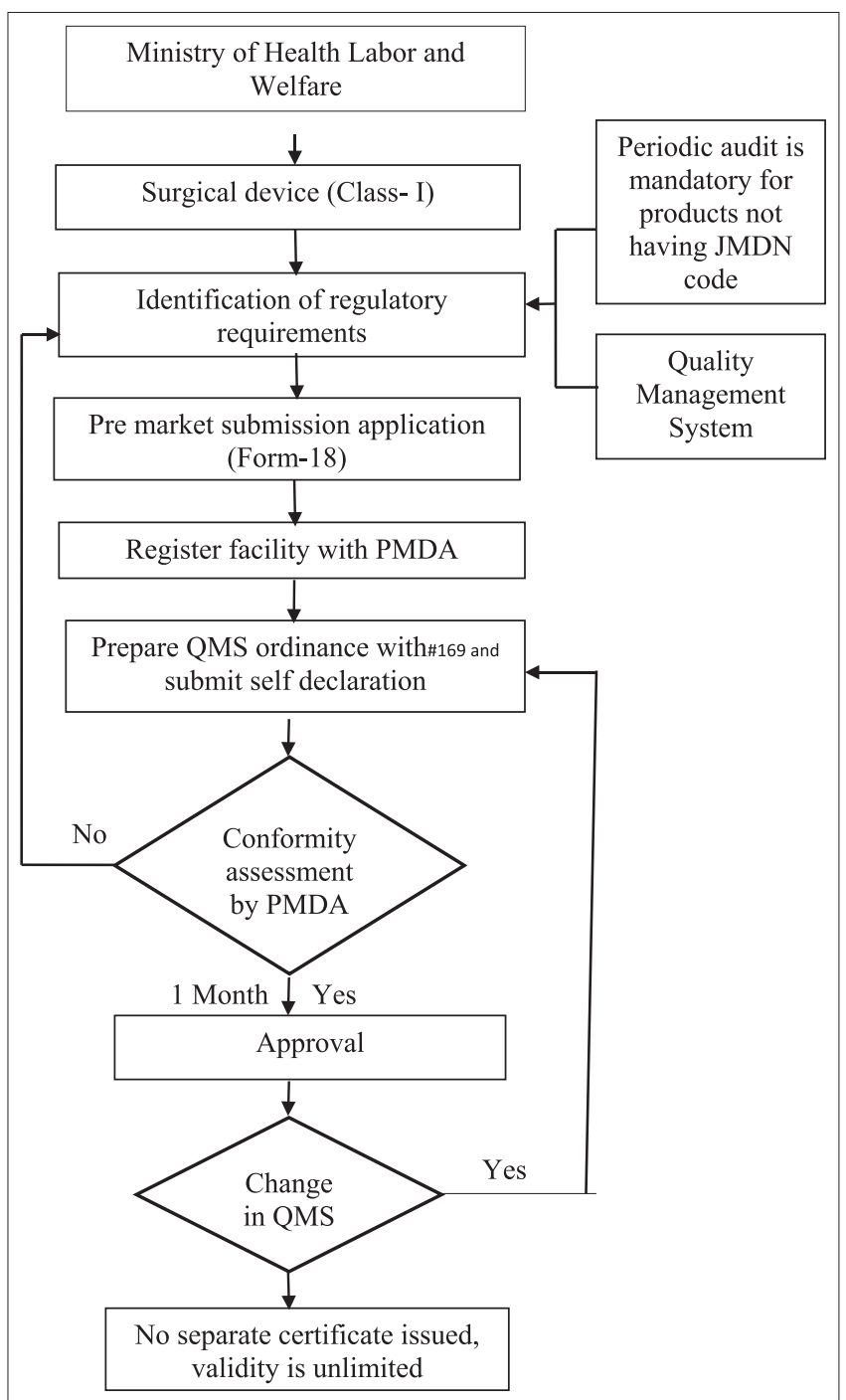

Fig. 3: Decision tree for the approval procedure in Japan [38] PMDA; Pharmaceutical and Medical Device Agency, JMDN; Japanese Medical Device Number, MAH; Marketing Authorization Holder

- ISO 13485:2003 quality system management

- Safety and effectiveness data.

- Step 3 (submission of MDEL): Application for an MDEL, that is, a permit for the distributor/importer, or a manufacturer of Class I devices. Submission of the MDEL application for Class I devices.

- Step 4 (fee submission): After submitting an MDEL application, payment of CAD $\$ 7344$ should be submitted within 30 days to the appropriate authority.

- Step 5 (review of MDEL application): The MDEL application is reviewed by the Canadian Registrar, and the approved application is posted on the Health Canada website.

- Step 6 (renewal and validity): Following approval, no separate certificate is issued, and under section 48 of the regulations, license holders are required to notify the health authority within 15 days in case of a change in the name or address of the license holder, or a change in the name, title, or telephone number of the contact person identified on the application.

Renewal is not required as licenses have an unlimited period of validity, but the MAH is required to pay an annual fee to Health Canada, and failure to do so may result in the license being revoked. The full procedure is outlined in Fig. 4 [40-42].

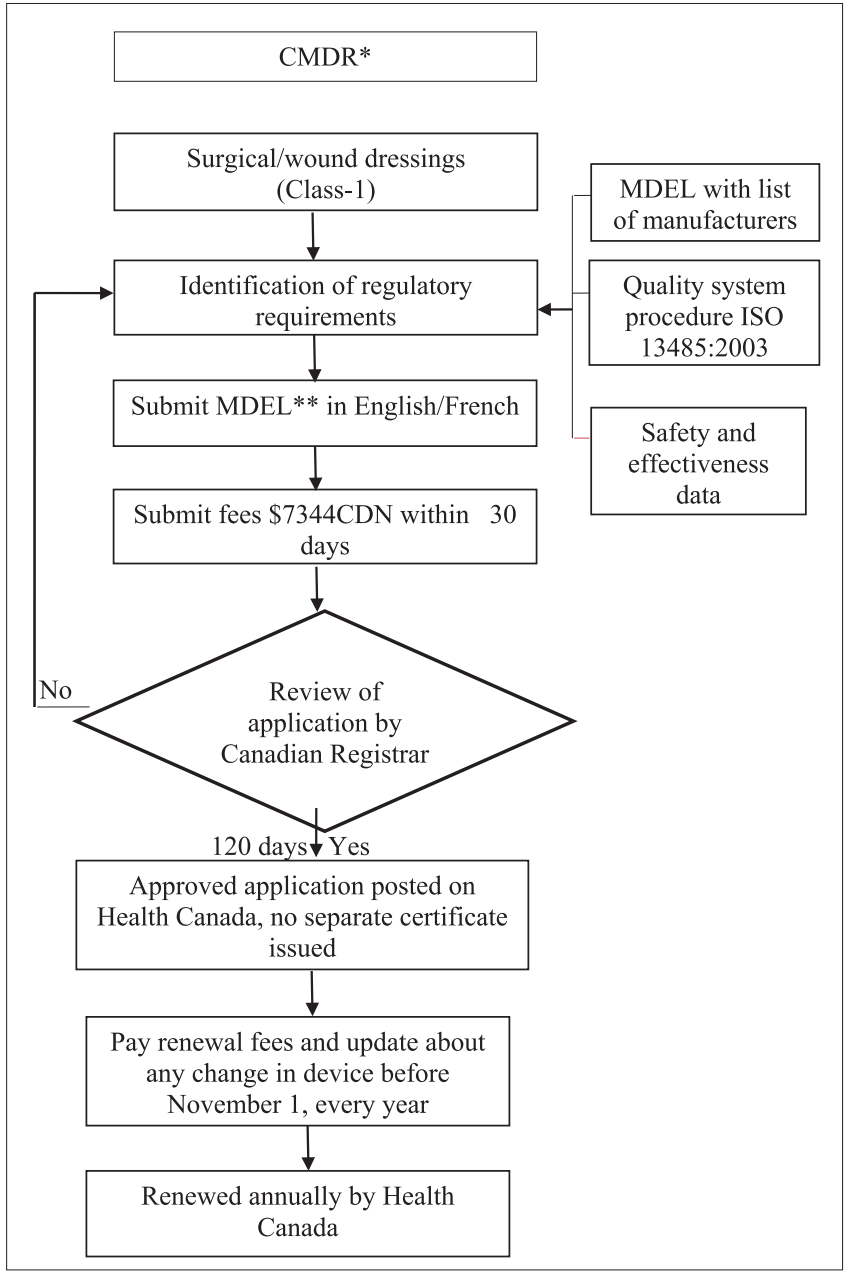

Fig. 4: Decision tree for the approval procedure in Canada*Canadian Medical Device Regulation;**Medical Device Establishment License; No fees for Class 1 devices

\section{Australia}

In Australia, surgical and wound care dressings are regulated by the Therapeutic Goods Administration (TGA). To obtain access to the Australian market, manufacturers are required to register their product on the Australian Register of Therapeutic Goods (ARTG). Regulations and classification of wound care dressings are similar to those in Europe $[29,43]$.

The full approval process, along with the necessary requirements for application, is outlined in Fig. 5.

- Step 1 (determination of classification): Correct classification of the product is required to register the product in Australia. Classification can be determined with TGA schedule 2 regarding Australian Therapeutic Goods (Medical Devices) Regulations, in which devices are categorized as either Class I (non-sterile and non-measuring) or Class I (sterile and measuring).

- Step 2 (identification of regulatory requirements): Before submitting the application for approval, applicants should make available the documents listed below:

- Manufacturer evidence of EU approval/CE marking or Global Medical Device Nomenclature (GMDN) code. If the device has already obtained CE marking, the TGA approval process is simplified, as Australia recognizes CE marking.

- Online application in the eBusiness Services system

- Australian sponsor

- Audit fees

- Declaration of conformity. 
- Step 3 (application submission): The Australian sponsor submits the medical device application online. The application should include an intended purpose statement, classification, and GMDN code.

- Step 4 (application review): The application is reviewed by the Australian regulatory body, and an assessment report is prepared. On the basis of the assessment report, a TGA audit of the facility is decided.

- Step 5 (approval/rejection): TGA will approve or reject the application and, if successful, issue a listing number for the ARTG.

- Step 6 (renewal and validity): The validity of the approval is unlimited as long as there are no changes to the product or its intended use, and the ARTG listing fee of AUD\$ 60 is paid annually [43-46].

Brazil

In Brazil, approval is required to market any health, domestic, or imported products by the MOH. The National Health Surveillance Agency (Agência Nacional de Vigilância Sanitária, ANVISA), a federal agency subsidiary to the $\mathrm{MOH}$, is responsible for the regulation, control, and supervision of products and services that pose a risk to public health. ANVISA issued the Resolution of the Board of directors (RDC) No. 185, which regulates the registration of medical devices and classifies them into four classes according to the risks associated with their use $[29,47]$.

\section{Approval process for surgical dressings}

Surgical device manufacturers are required to obtain ANVISA approval before selling their products in Brazil. The regulatory requirements for approval are similar to those identified in the European MDD 93/42/ EEC 65.

- Step 1 (determining classification)

According to Annexure II of the Brazilian Resolution RDC 185/2001, surgical and wound care dressings are categorized as Class 1 medical devices (low risk). There are two registration routes: Cadastro

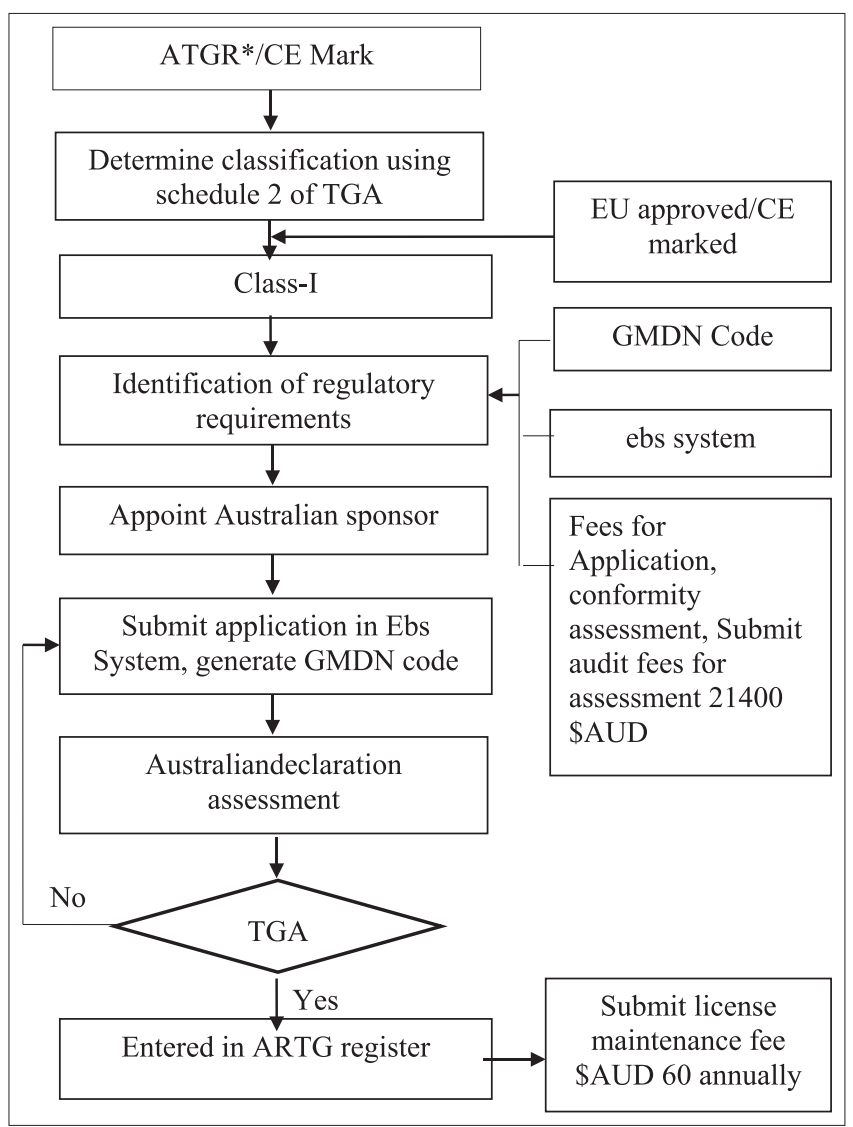

Fig. 5: Decision tree for the approval procedure in Australia. *Australian Therapeutic Goods Regulations, ARTG; Australian Register for Therapeutic Goods and Registro, and it is important to determine whether the device requires the Cadastro or the Registro approval process. The Cadastro process pertains to lower risk devices. As such, wound care dressings require approval through the Cadastro approval process. This review process has a simpler application pathway and typically requires less time than Registro approvals [47-50].

- Step 2 (identification of regulatory requirements)

The following are required:

- Manufacturing unit prepared in line with Brazilian Good Manufacturing Practices (BGMP)

- Labeling in Portuguese

- Proof of registration in other countries

- Technical file, if previously prepared for either the USA or the EU regulatory body.

Other possible ways to satisfy the requirements for all devices include obtaining a Certificate of Free Sale, or a device registration certificate proving home-country approval from $\mathrm{MOH}$, or demonstrating a proof of registration in any two other markets with reasons why the device does not have home-country approval.

- Step 3 (appointment of a Brazilian registration holder [BRH]) Company that holds a company working allowance permit from ANVISA should be appointed, as the BRH.

- Step 4 (application submission): Provide a letter of authorization to the $\mathrm{BRH}$, who will submit the registration application and technical file to ANVISA.

- Step 5 (BRH audit): Class I device manufacturers (Cadastro) must comply with BGMP requirements (ANVISA will not conduct an audit).

- Step 6 (application review): ANVISA reviews the registration application for all classes. If approved, ANVISA will publish the registration number in the Diário Oficial da União. Registration is valid for 5 years. The full procedure is outlined in Fig. 6 [47-50].

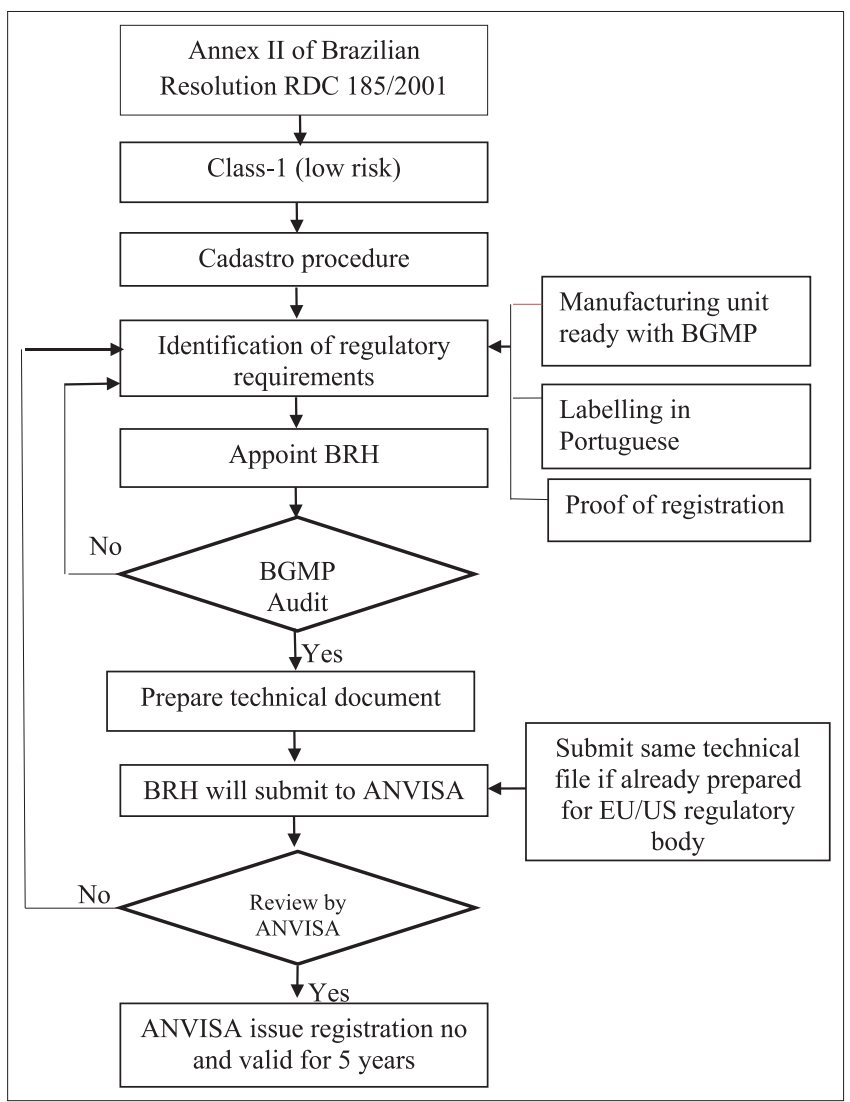

Fig. 6: Decision tree for the approval procedure in Brazil. BGMP: Brazilian good manufacturing practices, BRH: Brazilian registration holder, and ANVISA: National Health Surveillance Agency, Brazil 


\section{China}

The China FDA (CFDA) is responsible for the registration of wound care and burn dressings. It is mandatory to obtain pre-market approval from the State FDA (SFDA). The Center for Medical Device Evaluation (CMDE) is responsible for the registration process. The general administration of quality supervision, inspection, and quarantine is responsible for mandatory safety registration, certification, and inspection of certain devices. The procedures for wound care dressing registration are governed by two main regulations. Both regulations describe the legal requirements for medical device registration in China [29,51].

The SFDA registration process is divided into five steps, and the complete application procedure takes 105 working days, excluding the time period for testing or conducting clinical trials. The full procedure is outlined in Fig. 7.

- Step 1 (classification of product): The Chinese classification system for medical devices is similar to the European system; however, there are differences and applicants are advised to carefully consult the classification list published by SFDA. With reference to the published SFDA list, surgical and burn dressings are categorized as Class III medical devices.

- Step2 (identification of regulatory requirements): Before application for market approval, applicants should make available the requirements listed below:

- Completed application form for the device

- Legal qualification certificate

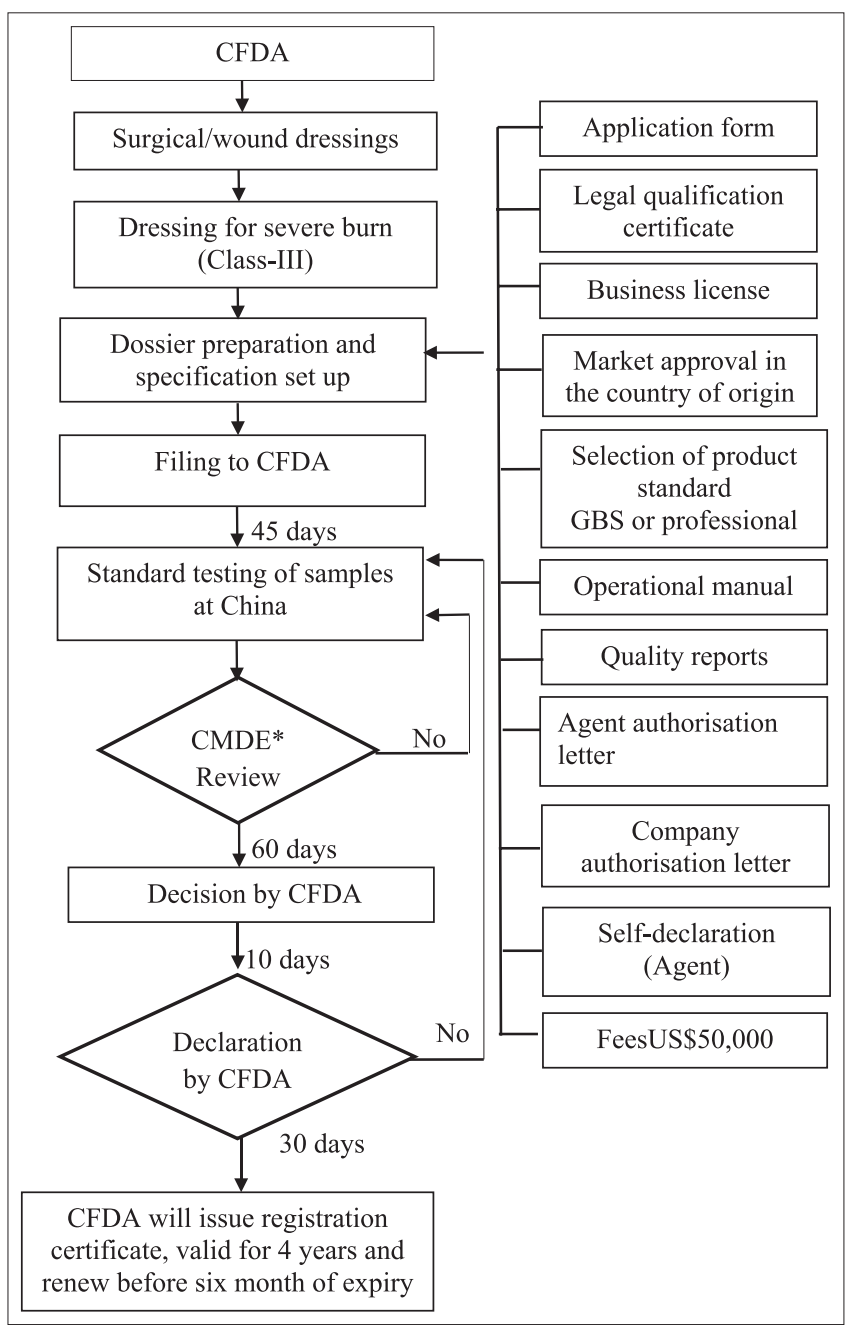

Fig. 7: Decision tree for the approval procedure in China. *CDME: Center for Medical Device and Evaluation, SFDA: State Food and Drug Administration, CFDA: China Federal Device Authority
- Business license

- Market approval in the country of origin

- Product standard selection

- Operational manual

- Quality reports: Clinical trial reports, if available

- Agent authorization letter

- Company authorization letter

- Self-declaration

- $\quad$ Required fee of US\$50,000.

- Step 3 (appointment of an agent): A legal agent should be appointed to submit an application and issue a letter of application stipulating the relationship between the agent and manufacturer.

- Step 4 (dossier preparation and application submission): Once medical device specifications have been completed and the required documents have been compiled, as identified in Step 2, the application should be submitted to SFDA for CMDE review.

- Step 5 (testing review of application): After submission of applications to CMDE, sample testing is undertaken in China. As stated in the regulations, sample tests must be completed within 45 working days. When sample tests have been completed, and the applicable fees have been paid, the test laboratory will issue a report (valid for 6 months) to be submitted as part of the medical device registration.

Type testing may be avoided if the imported medical device meets the following criteria:

- The medical device has previously received market approval by the relevant authority in the country of origin

- The manufacturer holds a valid ISO 9000 (or equivalent) certificate

- No significant differences exist between the device for application and device registered in terms of structure, performance, and safety.

- $\quad$ Step 6 (evaluation)

Technical evaluation involves systematic examination that focuses on the safety and effectiveness of the medical device. The evaluation is performed by internal CMDE reviewers and may involve external experts. On completion of the technical evaluation, CDME will issue an evaluation report indicating its judgment on the device. The evaluation report is submitted to SFDA for final approval. According to related regulations, SFDA may send an inspection/auditing group to manufacturers abroad to check for their quality assurance system based on Chinese National Standards GB/T 19001-IS09001, 19002-IS09002, and any other relevant medical device standards and registered product standards. CMDE will review the application and decide within 60 days. CFDA will respond within 10 days and provide a registration certificate within 30 days. A decision tree for the approval procedure in China is outlined in Fig. 7 [51].

\section{Singapore}

The Health Sciences Authority (HSA) is the regulatory authority responsible for the marketing of wound care and burn dressings in Singapore. According to the act and regulations, all sterile wound care dressings in Singapore must be registered for approval before placement in the Singapore market, unless it is stated that registration is not required. Product registration is not required for non-sterile dressings, although they must conform with the regulations before their placement in the Singapore market [52].

The full approval procedure is detailed below, and the flowchart for the procedure is shown in Fig. 8.

- Step 1 (classification of surgical dressings):

- Class A, non-sterile dressings: Class A, non-sterile dressings do not require registration with HSA, although they must conform with the essential principles of safety and performance of the products before entering the Singapore market.

- Class A, sterile dressings: Class A, sterile dressings require submission of an application dossier through the Medical Device Information and Communication System (MEDICS), and a payment of an application fee is immediately required on submission.

- $\quad$ Step 2 (identification of regulatory requirements) 


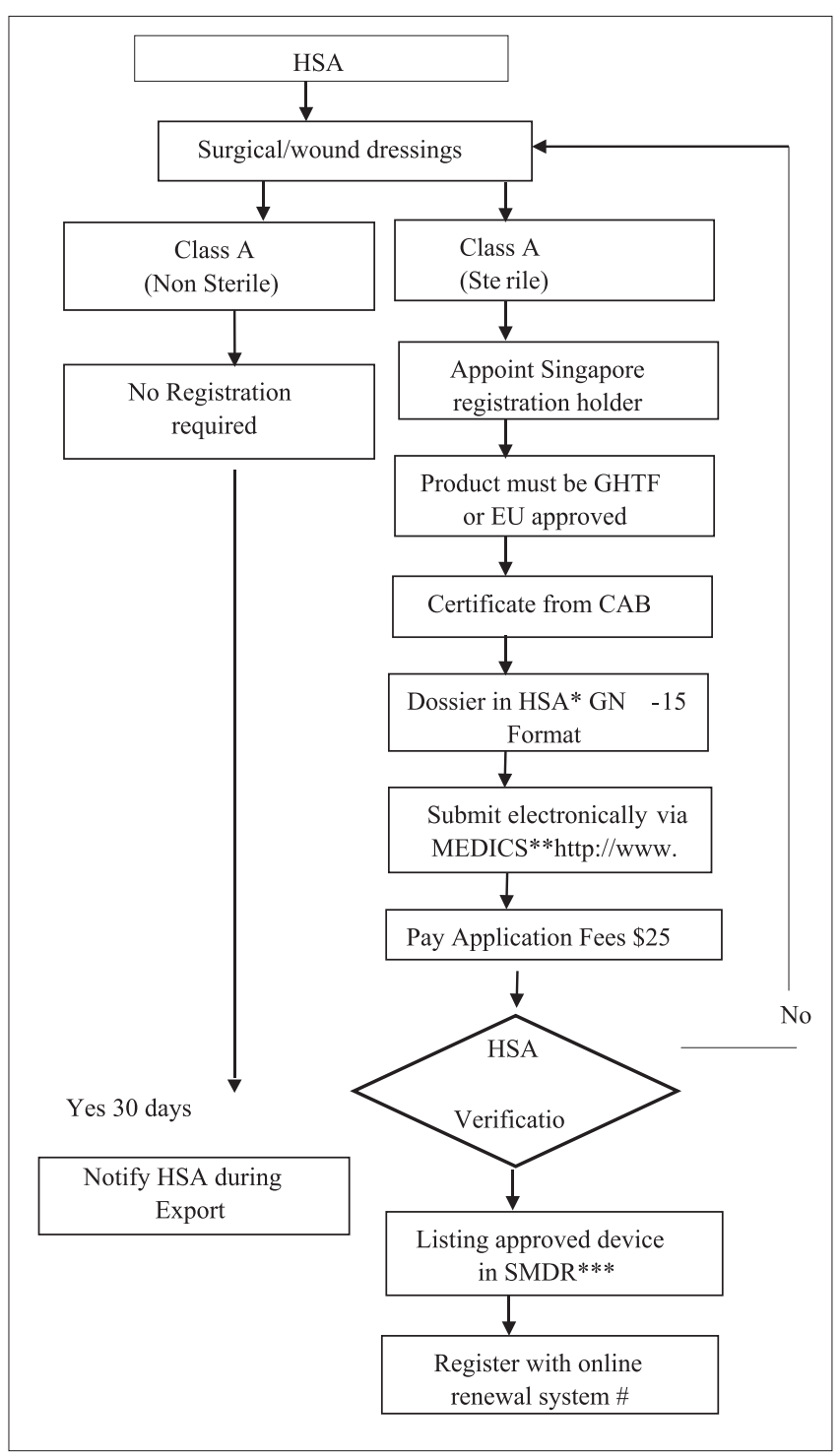

Fig. 8: Decision tree for the approval procedure in Singapore ${ }^{*}$ Health Science Authority, ** Medical Device Information and Communication System, ${ }^{* * *}$ Singapore Medical Device Register, and CAB: Confirmatory Assessment Board

\section{General requirements}

- The product must be approved by the Global Harmonization Task Force (GHTF) or must be EU-approved

- Certificate from the conformity assessment board

- Dossier in HSA, Guidance Notification (GN-15)format

- Submission through MEDICS

- Submission of fees.

\section{Documents required for Class A (sterile) dressings}

- Letter of authorization

- Proposed device labeling

- A list of all materials of animal, human, microbial, and/or recombinant origin used, and the manufacturing process, if applicable

- Sources of all materials of animal, human, microbial, and/or recombinant origin used, and the manufacturing process (if applicable)

- Information on sterilization method(s) and validation standard(s) used

- Proof of QMS, for example, ISO 13485 certificate, conformity to USFDA quality system regulations.
A non-sterile dressing is exempt from fees; however, the application fee for sterile dressings is $\$ 25$, and there is no evaluation fee. In general, market approval for sterile dressings can be obtained within 30 working days.

- Step 3 (submission of application): The dossier is submitted in HSAGN-15 format, electronically through MEDICS.

- Step 4 (review of application dossier): The review conducted by the HSA is based on the supporting data, which have been submitted by the applicants. If clarification or additional information is required, HSA will request further information from the applicants. A regulatory decision and listing in the Singapore Medical Device Register (SMDR) for successful registration, on review of the application submitted, is made by HSA. Applications that have satisfied the registration requirements are then registered and listed in SMDR. The approval timeline for these types of dressings is 1 month.

- Step 5 (evaluation process) - full evaluation route: Surgical dressings that have not been approved by any of the $\mathrm{H}$ as reference agencies will be subjected to the full evaluation route.

\section{Abridged evaluation route}

Surgical dressings that have been previously registered with at least one HSA reference regulatory agency for a labeled use identical to that intended for marketing in Singapore are eligible for the abridged evaluation route. A decision tree highlighting the approval procedure in Singapore is provided in Fig. 8 [52-61].

\section{Malaysia}

The Malaysian medical device regulatory framework is based on the global harmonization trend, as promoted by GHTF, the Asian Harmonization Working Party and Medical Device Product Working Group of the Association of Southeast Asian Nations Consultative Committee for Standards and Quality, and supported by the WHO [29].

The Malaysian Medical Device Authority (MDA) is responsible for enforcing medical device regulations and medical device registration. The full approval procedure is outlined and highlighted in Fig. 9.

- Step 1 (classification): According to the Malaysian Medical Device Regulations, surgical and wound care dressings are categorized as Class A devices. Class A is further subdivided into Class A non-active and Class $A$ active sterile groups.

- Class A, non-active sterile dressings: Class A non-sterile devices do not require registration, but approval in the reference country is required. To market Class A non-sterile surgical dressings, it is mandatory to notify the MDA.

- Class A, active sterile dressings: Submission of an application dossier using the Common Submission Dossier Template (CSDT) format is required.

- Step 2 (identification of regulatory requirements): The medical device registration form requires the following components

- General information regarding the medical device

- Information regarding the manufacturer of the medical device

- CSDT

- Post-market vigilance history

- Declaration of conformity

- Attestation for registration

- ISO certificate

- Labeling

- Approval in reference countries.

- Step 3 (appointment of authorized representative): To register surgical and wound dressings in Malaysia, an authorized representative in Malaysia must be appointed.

- Step 4 (preparation and submission of dossier): The authorized representative prepares the registration application dossier and submits the application to the Malaysian MDA online.

- Step 5 (review of the dossier): An independent conformity assessment body (CAB) reviews the registration application dossier and issues a CAB certificate that is then submitted to the MDA. Fig. 9 details a decision tree for the approval procedure in Malaysia [62-66]. 


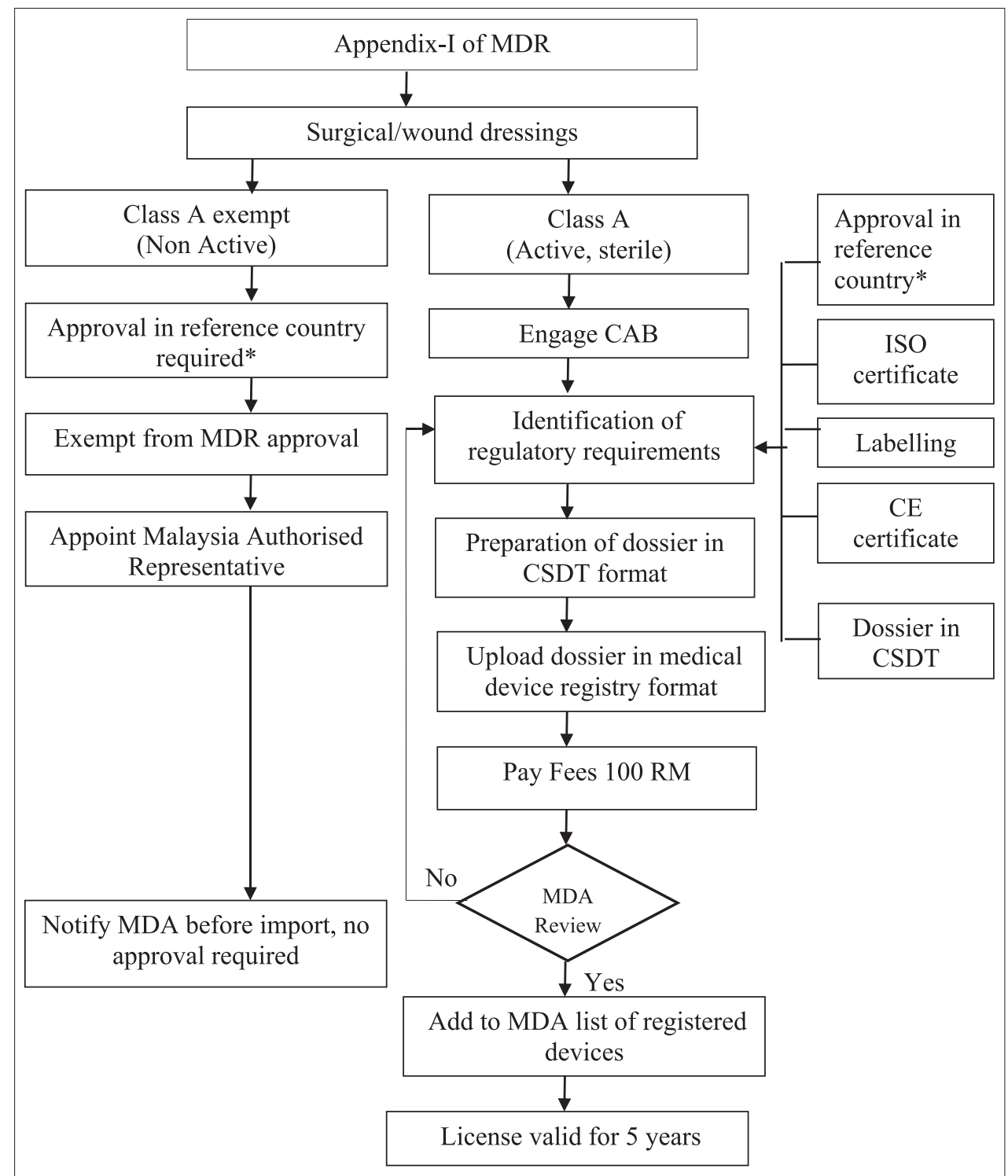

Fig. 9: Decision tree for the approval procedure in Malaysia. CAB: Confirmatory Assessment Body. *Recognized reference markets include: Australia, Canada, EU, Japan, and USA

\section{Mexico}

In Mexico, wound care and burn dressings are classified on the basis of the risk associated with their use. They are classified as medical devices and are regulated by the Federal Commission for Protection of Sanitary Risks (Comisión Federal para la Protección contra Riesgos Sanitarios, or "COFEPRIS"), which is a division of the Secretariat of Health (Secretaría de Salud).

Foreign manufacturers are not permitted to submit registration applications directly to COFEPRIS and instead must appoint a Mexican distributor or local Mexican registration holder (MRH) to act on their behalf. The full approval procedure is described below and a detailed flowchart is provided in Fig. 10.

- $\quad$ Step 1 (classification determination)

The first step for registration in Mexico is to determine the class of the device. Wound care and burn dressings are categorized as Class I, that is, low-risk medical devices. Products within this category have been previously well-established, with a longstanding history of registration, approval, and proven safety and effectiveness, and are generally not introduced into the body. These products must be registered; however, technical data are not required to support registration.
- $\quad$ Step 2 (identification of regulatory requirements)

The following list outlines the documents that manufacturers must prepare, before applying for registration:

- Application form

- Device information

- Scientific and technical information

- Testing requirements

- Evidence of home-country approval

- Labeling in accordance with NOM-137 SSA-1-2008

- Instructions for the use of the device

- Description of the manufacturing process

- $\quad$ Valid GMP

- $\quad$ Product structure and bibliography.

- $\quad$ Step 3 (appointment of a local registration holder)

An MRH must be appointed, who is licensed by COFEPRIS and located in Mexico, and who will submit the application to COFEPRIS. The appointed MRH will also be responsible for coordinating importation of the device; therefore, the MRH must maintain warehouses that comply with COFEPRIS' specifications.

- $\quad$ Step 4 (COFEPRIS review)

A third-party reviewer (TPR) is a private commercial entity authorized by COFEPRIS to conduct an initial review of an application 


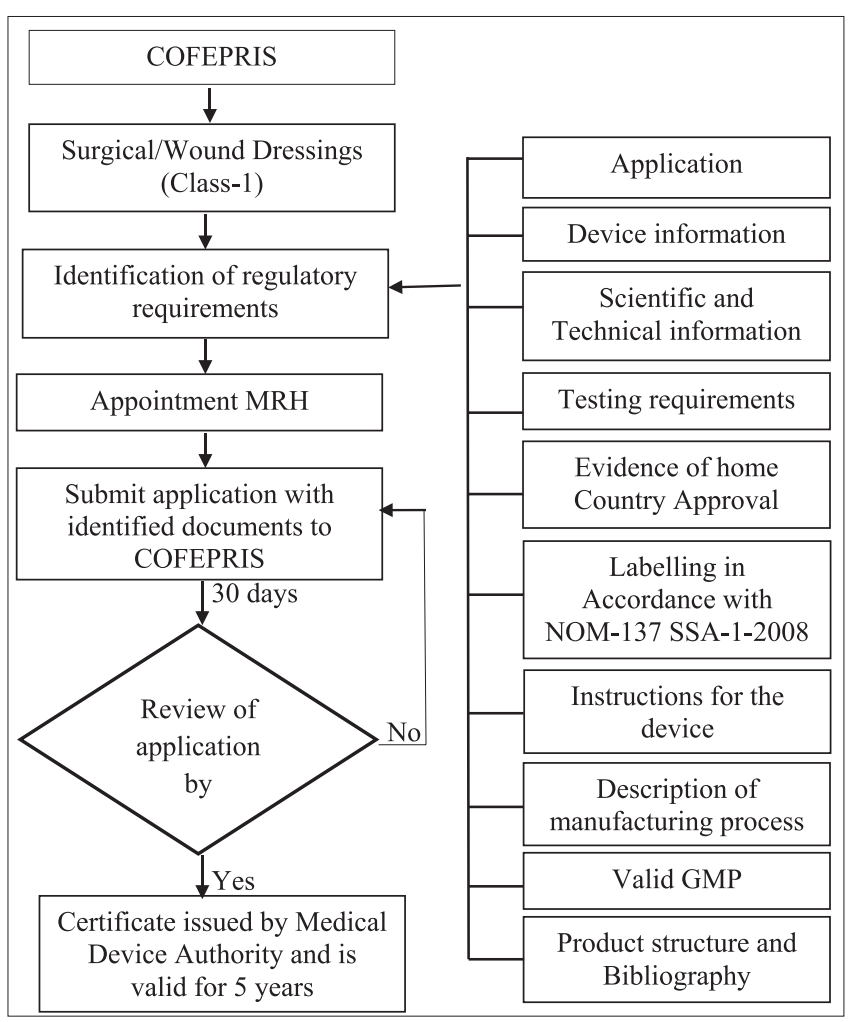

Fig. 10: Decision tree for the approval procedure in Mexico Fees is set by the authority on the basis of risk assessment, according to the federal law on fee payment. MRH: Mexican Residence Holder. \# SLA: State Licensing Authority, CLA: Central Licensing Authority. *Audit of Facility by Notified body is carried out after approval of Class A medical device

and, if satisfied, write a technical report for COFEPRIS recommending approval. While an additional cost is incurred for a TPR, typically no additional information will be required by COFEPRIS after the TPR issues their report. In addition, as TPRs are commercial entities, they may be more responsive and review applications more quickly, resulting in a shorter review process overall. After reviewing the report, if there are no further requests for information, COFEPRIS will issue the final registration certificate within 30 days.

- Step 5 (issuance of the certificate of approval)

Once COFEPRIS approves an application and issues a certificate, confirmation and registration number are posted on the $\mathrm{MOH}$ website. If COFEPRIS has any concerns with the registration, it will inform manufacturers in writing. On such occasions, the time limit for approval is lifted and longer time may be required to approve a registration. A decision tree for the approval procedure in Mexico is shown in Fig. 10.

- Step 6 (renewal and validity)

The certificate is valid for 5 years $[67,68]$.

\section{India}

Wound care and burn dressings in India are currently included in the new Medical Devices Rules 2017, under subsection (1) of section 12 and subsection (1) of section 3 of the Drugs and Cosmetics Act, 1940 [69].

Burn dressings are not classified separately in the Medical Devices Act, however, according to the medical device classification detailed in Schedule I, Part I, they are classified on the basis of their intended use.

- Step 1 (identification of classification)

Wound care and burn dressings are categorized as Class A-D medical device as in contact with injured skin. In addition, subject to clause (c), a non-invasive medical device in contact with injured skin shall be assigned a Class B categorization, as it is principally intended for the management of the microenvironment of a wound.

- Step 2 (identification of regulatory requirements)

The domestic manufacturer or authorized agent shall submit a signed form along with the following information pertaining to the manufacturing site as provided in Table 5 .

- $\quad$ Step 3 (submission of application)

The State Drugs Controller serves as the State Licensing Authority (SLA) and shall be the competent authority for enforcement of the rules relating to the manufacture of Class A or Class B medical devices and the sale, stocking, and exhibition of medical devices, and other related functions. Class C and D high-risk devices are regulated by the Central Licensing Authority (CLA), which oversees the clinical investigation and clinical performance evaluation of medical devices and has other related functions. If the manufacturer intends to manufacture a predicate medical device, the manufacturer must receive approval from CLA before applying to the SLA.

- $\quad$ Step 4 (issuing the license)

The manufacturing site of the applicant, in respect to a Class B device, shall conform with the QMS requirements, as specified in the fifth schedule, and the applicable standards, as specified under these rules, and such conformance shall be verified through an audit by a notified body as referred to under rule 13 before granting the license.

- $\quad$ Step 5 (validity and renewal)

A license issued using the MD-5 form shall remain valid in perpetuity, subject to payment of a license retention fee, as specified in the second schedule before completion of the period of 5 years from the date of its issue; unless it is suspended or canceled by SLA or CLA [68]. A decision tree for the approval procedure in India is provided in Fig. 11.

Israel

Israel is one of the world's leading centers for the development of innovative medical devices [71]. In Israel, wound care dressings are categorized as medical devices. All regulations related to medical devices are also applicable to wound care and burn dressings. Wound care dressings manufactured or marketed in Israel must be registered with the MOH Registrar (AMAR - the Medical Device Division of the Israeli MOH) [72].

Registration of wound care dressings in Israel is based on prior approval in one of the following countries: Australia, Canada, EU, Iceland, Norway, New Zealand, Switzerland, Japan, or USA.

The registration procedure for wound care dressings is described and the process flow is shown in Fig. 12.

- Step 1 (identification of classification)

Wound care dressings are categorized as medical devices, and all regulations regarding medical devices are applicable.

- Step 2 (identification of regulatory requirements) Manufacturers of wound care dressings should make available the following documents before applying for registration:

- FDA $510(\mathrm{k})$ pre-market approval

- Prior approval by GHTF is mandatory

- CE marketing certificate by European notified body

- Proof of ISO 13485 certification

- Certificate of free sale.

- Step 3 (appointment of an Israeli registration holder [IRH])

Following determination of the category, a local IRH must be appointed, licensed and located in Israel. The appointed IRH will also coordinate importation of the device and must maintain warehouses that comply with Israeli specifications. The IRH will submit the applications to AMAR.

- Step 4 (application submission)

The IRH will submit the above-listed documents to the AMAR-Medical Device Division of the Israeli MOH.

- Step 5 (review of application)

AMAR will review the application within 120 days; however, registration is usually completed within 6-9 months because 
Table 5: List of documents required for manufacturer registration and for importation of dressings

\begin{tabular}{|c|c|c|}
\hline Class A & Class B-D & Dressing other than predicate \\
\hline $\begin{array}{l}\text { For manufacturing } \\
\text { Device description } \\
\text { Intended use } \\
\text { Specification } \\
\text { Working principle and use of } \\
\text { novel technology, if any } \\
\text { Label package inserts } \\
\text { User manual } \\
\text { Summary of ADR } \\
\text { Site master file } \\
\text { Firm details } \\
\text { Signed undertaking agreement } \\
\text { Analytical performance } \\
\text { For importation }\end{array}$ & $\begin{array}{l}\text { Constitution details of domestic } \\
\text { manufacturer or authorized agent } \\
\text { Site or plant master file } \\
\text { Device master file } \\
\text { Essential principle checklist for } \\
\text { demonstrating conformity for safety and } \\
\text { performance } \\
\text { Quality control data } \\
\text { Signed undertaking agreement stating that } \\
\text { the manufacturing site is compliant with } \\
\text { schedule }\end{array}$ & $\begin{array}{l}\text { Data analysis } \\
\text { Design input/output documents } \\
\text { Mechanical and electrical test results } \\
\text { Reliability test results } \\
\text { Validation of software } \\
\text { Performance test results } \\
\text { Biocompatibility test results } \\
\text { Risk management data } \\
\text { Animal performance data } \\
\text { Pilot and pivotal clinical investigation data } \\
\text { Regulatory status and restrictions in use } \\
\text { Proposed instructions for use }\end{array}$ \\
\hline $\begin{array}{l}\text { Notarized copy of overseas mant } \\
\text { Notarized copy of QMS } \\
\text { Self-attested wholesale license } \\
\text { Copy of latest inspection report }\end{array}$ & or FSC & \\
\hline
\end{tabular}

FSC: Free sale certificate

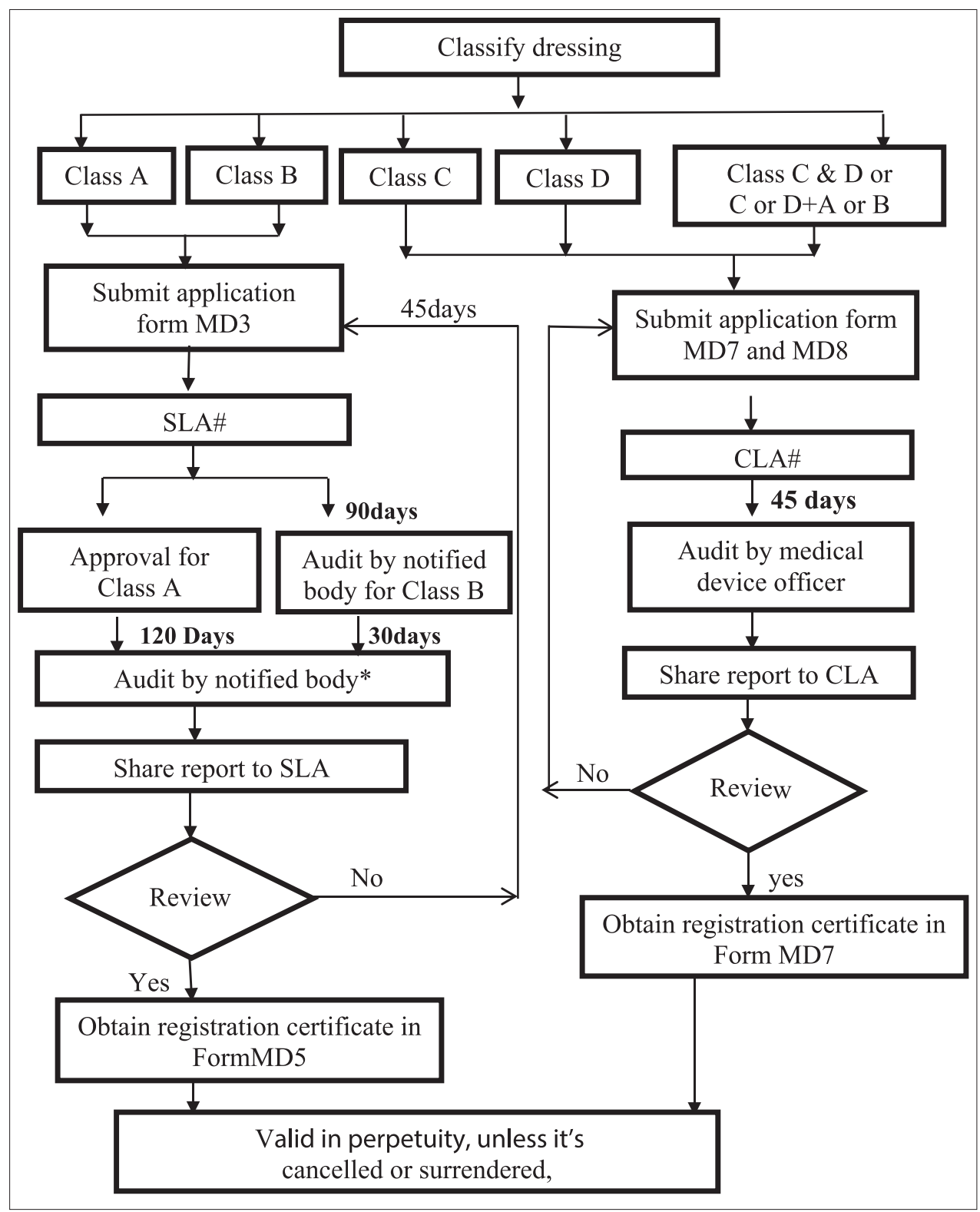

Fig. 11: Decision tree for the approval procedure in India [69-71] 


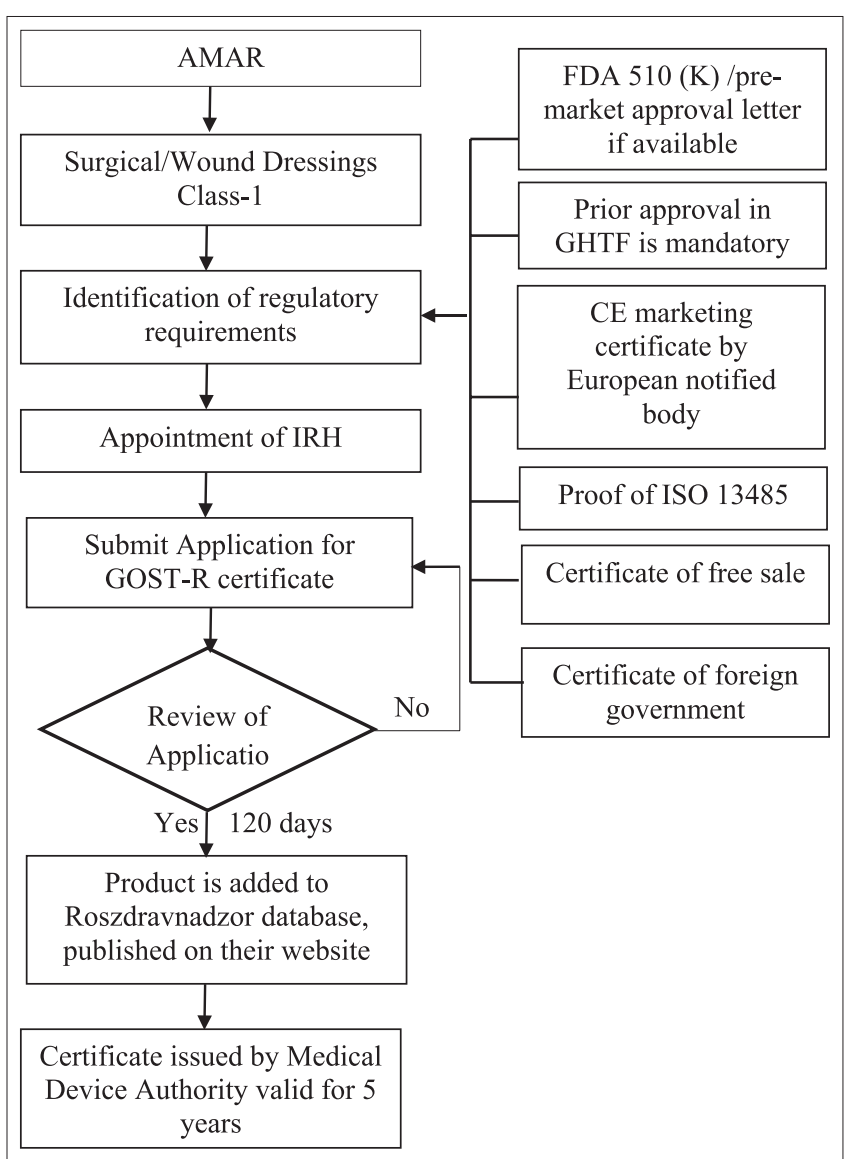

Fig. 12: Decision tree for the approval procedure in Israel [71,72]. GHTF: Global harmonization task force, AMAR; a department within the Israeli MOH responsible for licensing medical devices, and IRH: Israeli Residence Holder

authorities will often require further documentation during the course of the evaluation.

- Step 6 (issuance of certificate and validity)

After successful completion of all evaluation steps, AMAR will issue the registration certificate, which is valid for 5 years. The license expiration date is based on the current regulatory certificate and is subject to the device's CE mark or FDA approval. Fig. 12 details approval procedures in Israel.

\section{Russia}

In the Russian Federation, all wound care and burn dressings are categorized as medical devices. For diagnostic and therapeutic use, they must be registered in Moscow, at the Central Department of Federal Service on Surveillance in Healthcare and Social Development (Roszdravnadzor) [73].

- Step 1 (identification of classification)

In accordance with Government Standardization (GOST) R 516092000 medical products, surgical dressings/wound care dressings are categorized as Class I (products with a low risk for environmental, individual, and public health). Examples are medical devices used in hygiene, diagnostics, medication and nursing, single-use linen, dressing materials except for special and high-standard dressing materials, retentive bandages, and appliances. Applicants should determine whether a previously approved and/or equivalent device exists in the Russian Federation and confirm the classification of the device [74].

- Step 2 (identification of regulatory requirements):

- Certificate from the country of origin

- Proof of compliance

- IS013485
- Gosudarstvennyy standart Russian (GOST-R) testing requirements

- Application letter

- Power of attorney

- Description of manufacturing process

- Manufacturer operational manual

- Testing requirements of the product.

- $\quad$ Step 3 (appointment of a Russian registration holder [RRH])

Following determination of classification, a local registration holder should be appointed. An RRH must be licensed and located in Russia. RRHs coordinate importation of the device and must maintain warehouses that comply with Russian specifications. The RRH will submit applications to the Russian MDA.

- $\quad$ Step 3 (Dossier preparation)

If testing is required, an application for an import license for the samples is required, and sample testing is conducted at governmentauthorized testing and medical centers within Russia. Preparation of the registration dossier should include testing results and medical reports. All documents should be submitted to the relevant officials.

- $\quad$ Step 4 (application review)

Review of the application is undertaken within 120 days, and a certificate is issued if all test results and submitted documents have been approved. Fig. 13 details the decision tree for the approval procedure in Russia [73-75].

The comparative study (detailed below in Table 6) shows that some countries have heavy fees levied on the MAH for product registration and license maintenance that restrict the marketing of innovative products despite posing no risks to health.

\section{DISCUSSION}

From the details provided above, it is apparent that, for all countries mentioned, wound care and burn dressings are categorized under medical devices, and therefore, respective regulations are applicable on wound care and burn dressings. Despite the similar classification system in several countries, differences remain in various documentation requirements and dossier content submission, as well as in evaluation procedures. Differences, regarding dossier submission format, are detailed in Table 7.

The main difference in the content and format of import and export licenses for regulated and semi-regulated countries lies in the different classification of the same dressing. Some countries share a harmonization process; if a device is approved in one country, it may then be exported, due to mutual recognition agreements. Australia generally requires products with a CE mark. In India, dressings with FDA approval or EU mark may be approved and marketed more readily.

The various challenges encountered while drafting quality guidelines prevent the development of these guidelines, and also restrict manufacturers from maintaining the quality of the products. The following gaps/challenges are identified:

\section{Wound size and type}

Quantitative measurements of wound sizes are routinely used to assess an initial wound pre- and post-debridement. There are no standardization/validation guidelines for instruments such as Doppler sonography and filament testing used in the assessment of wound types [78].

\section{Unavailability of quality testing parameters/guidelines/} monographs

To harmonize the quality of new products, there should be suitable test procedures in monographs [78].

\section{Absence of suitable guidelines for clinical trials}

The included patient population in clinical trials should be appropriate for the type of wounds to be studied. The selected patient population 


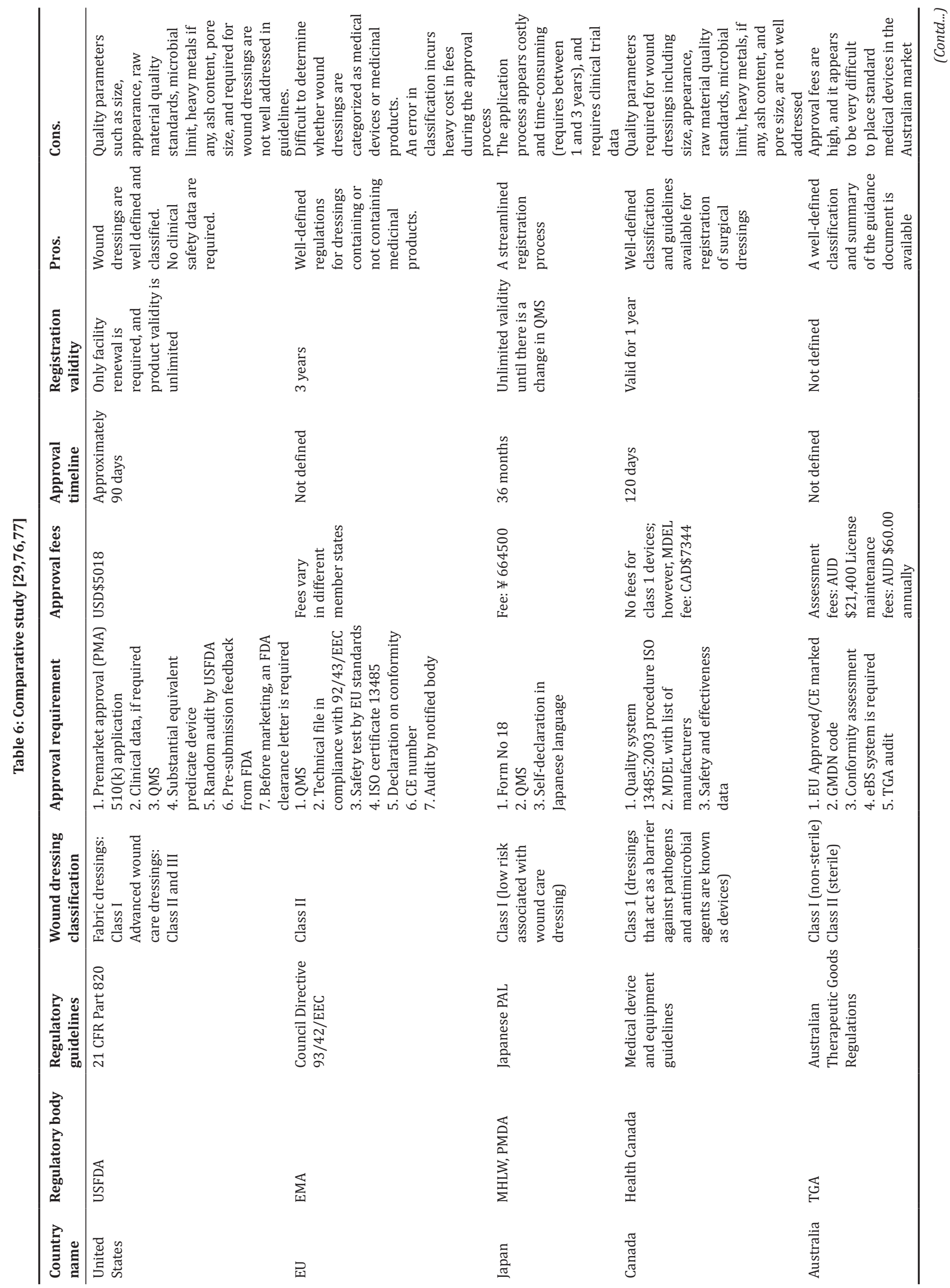




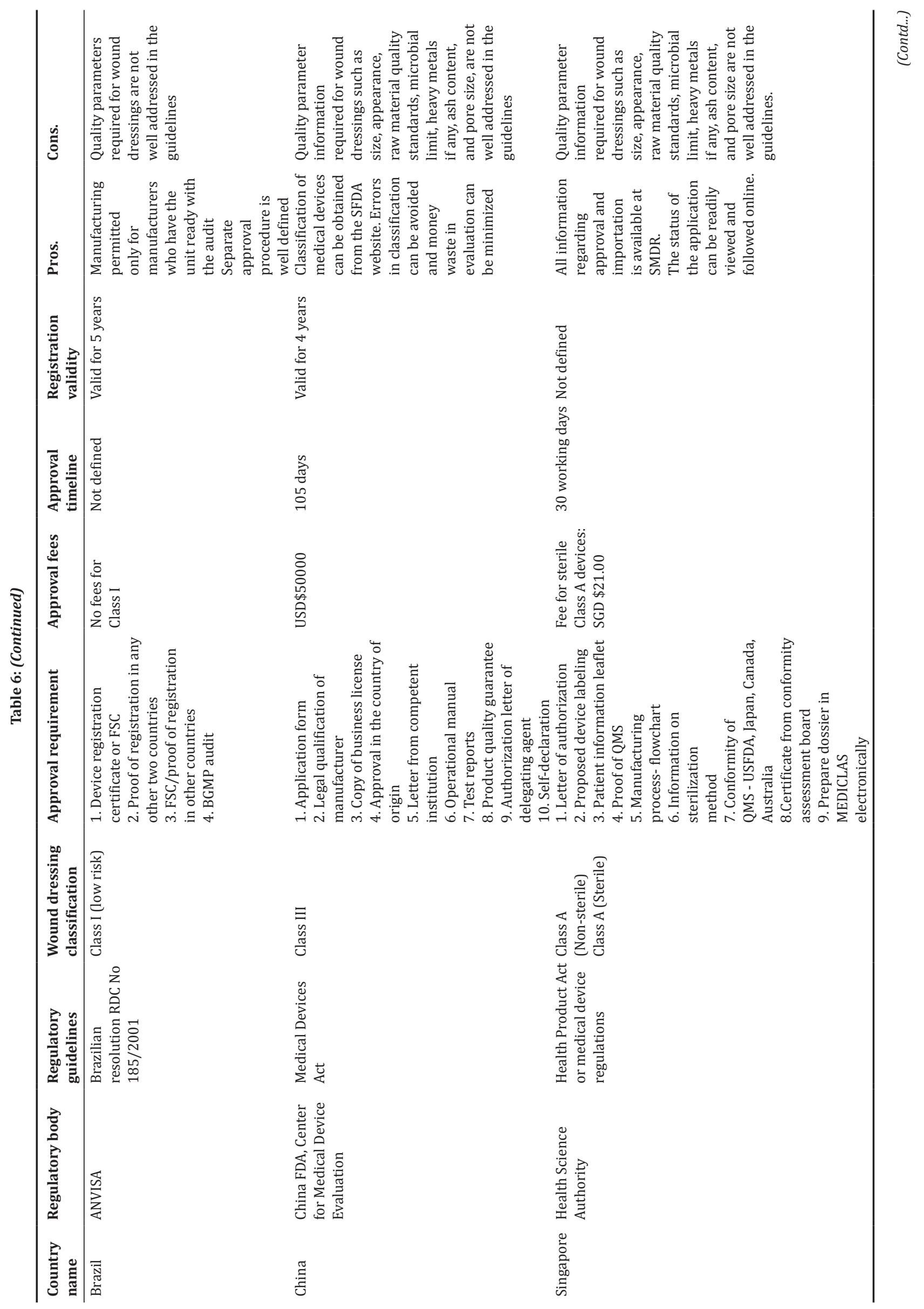




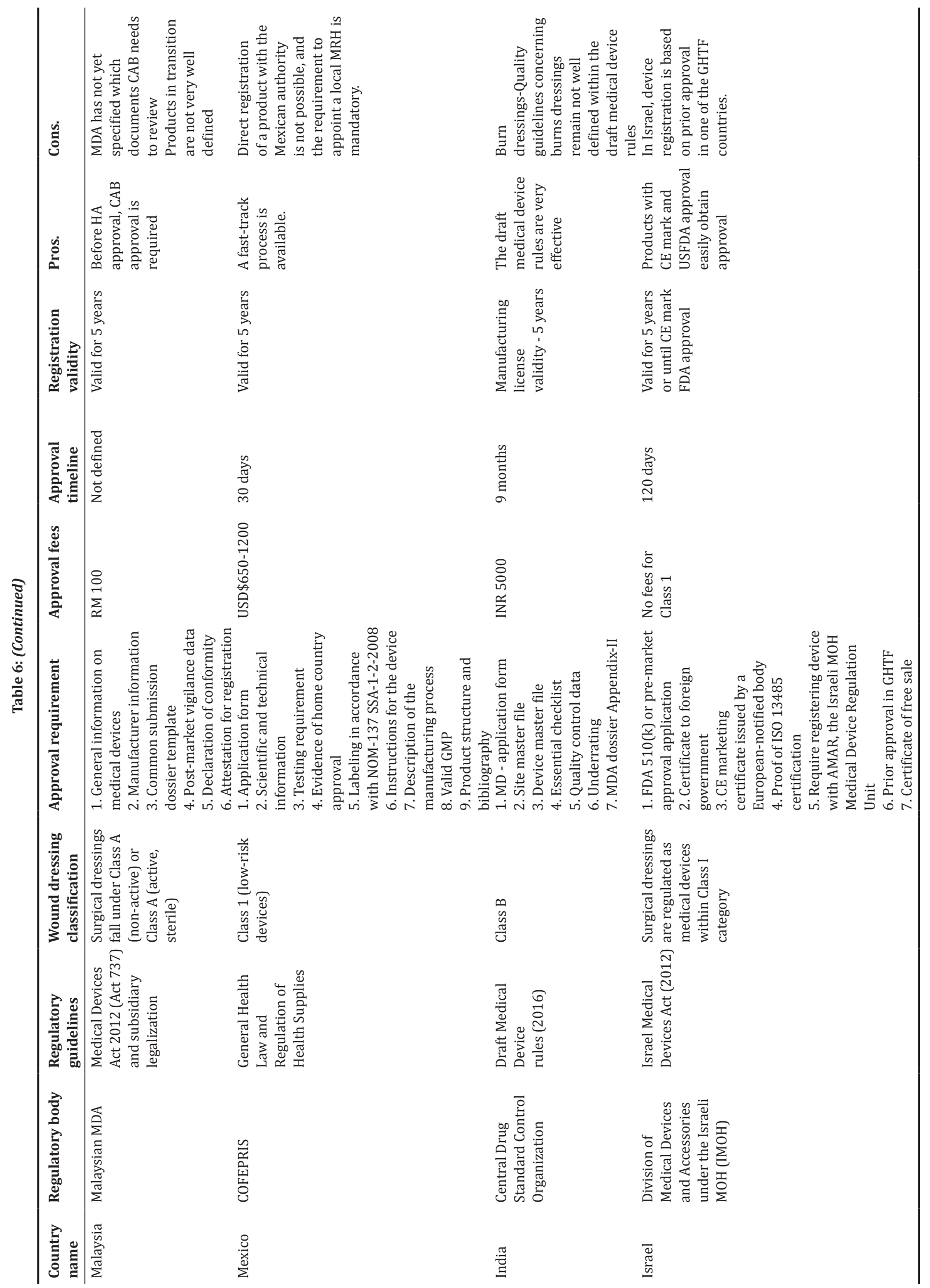




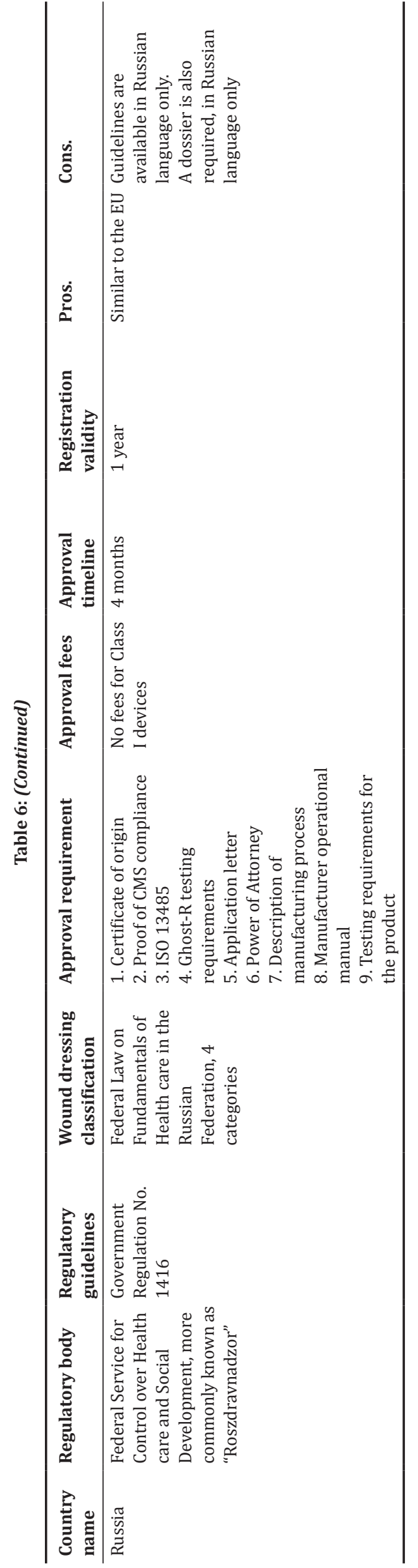

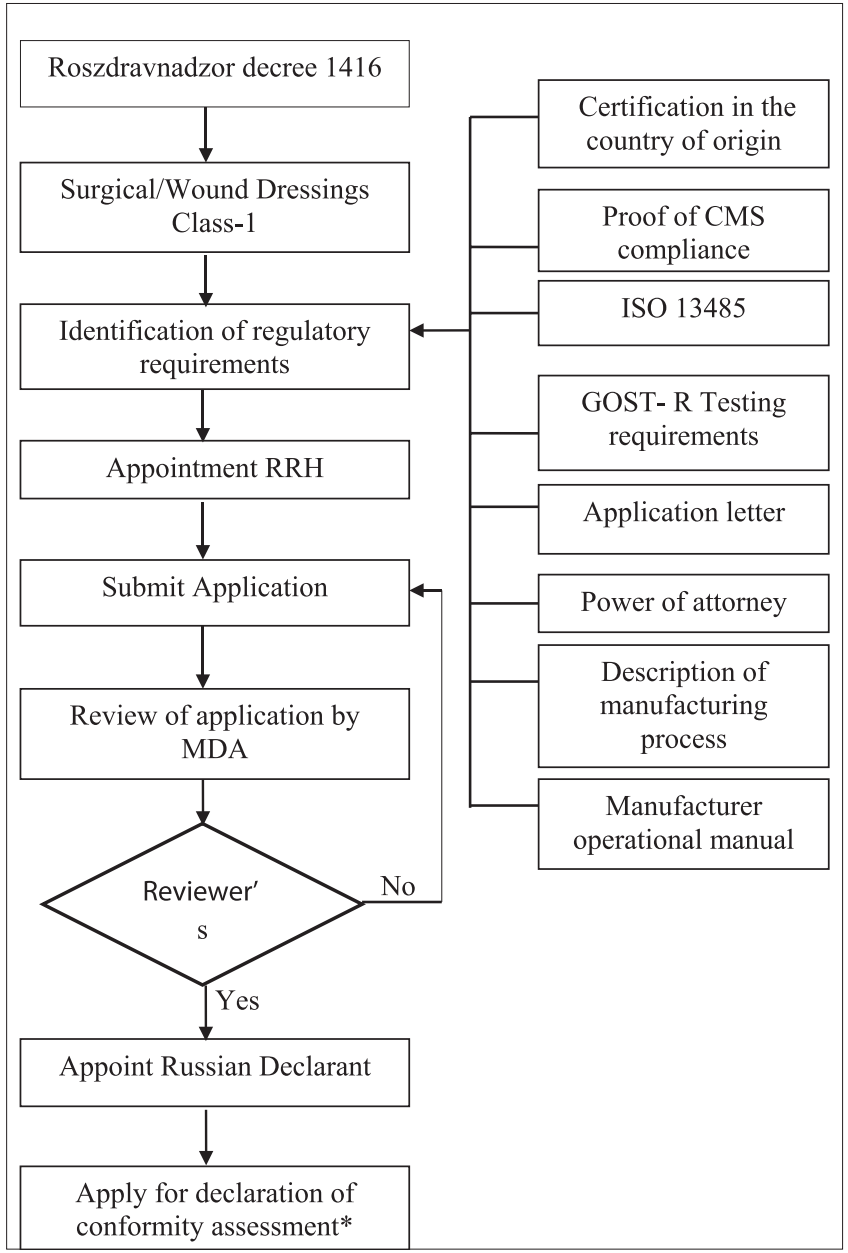

Fig. 13: Decision tree for the approval procedure in Russia. Roszdravnadzor; Federal service for control over health care and social development, RRH: Russian Resident holder. *Conformity Assessment: A declaration certifying that the product conforms with Russian Regulatory Requirements

should contribute to the optimization of the study's capacity to detect a treatment effect. There are no available ideal animal models for chronic/ extensive wounds to assess the activity of wound treatment products. There are no ideal animal models for chronic wounds to estimate in vivo distribution and pharmacokinetic (BD/PK) profiles, which generally provide helpful data for the design of toxicology studies including carcinogenicity, and reproduction, and genotoxicity studies [78].

\section{Microbial control}

There is no specific procedure for the sterilization of different wound care products [78].

Missing suitable selection procedures for the use of dressings Selection of wound care dressings generally depends on the type of wound. For burns, the selection procedure should include the burn site, extent of burn, type of first aid used, patient ability to manage the dressings, cause of the burn, associated pain, urgency of time healing, and cost [78].

\section{Miscellaneous challenges}

According to Bairy et al. [79], "burns afflict all segments of society, the rich, the poor, men and women, and children and old may fall victim to it." Scientists and firms face various challenges in the development of new therapies or products for wound care and burn dressings. Clearly, this is a complicated and difficult process with many potential pitfalls. It is difficult to acquire sufficient funding and navigate the 
Table 7: Differences in content and formatting of forms in regulated and semi-regulated countries [29]

\begin{tabular}{|c|c|c|}
\hline Country name (regulatory agency) & Classification & Dossier submission format for approval \\
\hline United States (USFDA) & Class II & $\begin{array}{l}\text { Application in } 510(\mathrm{k}) \text { format is required, FDA QMS is } \\
\text { mandatory. A plant audit is to be undertaken by the FDA }\end{array}$ \\
\hline EU (EMA) & $\begin{array}{l}\text { Class I (non-sterile) } \\
\text { Class I (sterile) }\end{array}$ & $\begin{array}{l}\text { No dossier submission is required, compliance with directive is } \\
\text { sufficient, and the CE mark can be used }\end{array}$ \\
\hline Japan (PMDA) & Class I & $\begin{array}{l}\text { No certification or dossier is required. Compliance with QMS } \\
\text { accordance with \# } 169 \text { is required }\end{array}$ \\
\hline Canada (Health Canada) & Class I & Submit the dossier in French \\
\hline Australia (TGA) & Class I & $\begin{array}{l}\text { Submission of available CE mark or the FDA QMS is sufficient. } \\
\text { A conformity assessment certificate should be provided }\end{array}$ \\
\hline Brazil (ANVISA) & Class I & $\begin{array}{l}\text { Dossier in accordance with RDC } 185 / 2001 \text {, copy of payment of } \\
\text { fees, identification of manufacturer, free trade certificate, and } \\
\text { declaration of conformity }\end{array}$ \\
\hline China (CFDA) & Class III & $\begin{array}{l}\text { A sample and specification are required with the dossier; QMS } \\
\text { is not mandatory }\end{array}$ \\
\hline Malaysia (MDR) & Class A & Dossier is required in an electronic format \\
\hline India (CDSCO, DCGI) & Class A, B, C, D & Dossier submission in the form of a technical list \\
\hline Singapore (HAS) & Class A & $\begin{array}{l}\text { Dossier submission in electronic form and an HASF format is } \\
\text { required }\end{array}$ \\
\hline Mexico (COFEPRIS) & Class I & $\begin{array}{l}\text { Dossier with specific labeling required, in accordance with } \\
\text { regulation NOM-137 SSA-1-2008 }\end{array}$ \\
\hline $\begin{array}{l}\text { Israel (Medical Institutions and Device Licensing } \\
\text { Department) }\end{array}$ & Class I & Prior registration with GHTF is mandatory \\
\hline Russia (Federal Services on Health-care Supervision) & Class I & Testing in the country of origin is required \\
\hline
\end{tabular}

regulatory environment. Furthermore, when increasing production, addressing logistics, and managing the cost of goods, manufacturing sites may compromise profitability and risk the long-term viability of the enterprise [76-78].

Systems for approving advanced dressings must clearly define pathways to market important innovations while also ensuring that patients are adequately protected. To achieve these goals, there should be a combination of premarket testing and post-market vigilance but with some marked contrasts in their approaches. Features of both environments require reform, as well as continuous research to assess policy changes.

\section{CONCLUSION}

Wounds are inescapable events in life. Wounds may a rise due to physical, chemical, or microbial agents [80]. Our study reveals that wound care dressings are classified as medical devices and are categorized based on the risks associated with their use. Despite categorization as medical devices, wound care dressings are not clearly defined in any country. Most current challenges include the lack of a proper definition, quality standard specifications, requirements for preparation of the dossier, drawings and designs, and the quality of materials to be used. It has been identified that there is no specific or common dossier format available globally for market approval of such dressings. Systematic guidelines regarding wound care dressings are likely to help overcome delays in regulatory approval and will provide a better understanding to manufacturers and innovators about the specific requirements.

\section{AUTHOR'S CONTRIBUTIONS}

Vibhu Yadav: Gathered data and prepared the manuscript. Parikshit Bansal and Amit Mittal: Provided the idea, supervision, and guidance for this work. Sachin Kumar Singh: General formatting and preparation of the manuscript.

\section{CONFLICTS OF INTEREST}

The authors declare no conflicts of interest.

\section{REFERENCES}

1. Rowan MP, Cancio LC, Elster EA, Burmeister DM, Rose LF, Natesan S, et al. Burn wound healing and treatment: Review and advancements.
Crit Care 2015;19:243

2. Madaghiele M, Demitri C, Sannino A, Ambrosio L. Polymeric hydrogels for burn wound care: Advanced skin wound dressings and regenerative templates. Burns Trauma 2014;2:153.

3. Wasiak J, Cleland H, Campbell F, Spinks A. Dressings for superficial and partial thickness burns. Cochrane Database Syst Rev 2013;3:CD002106

4. Mediligence Blog. Wound Prevalence and Wound Management 20122020. Medmarket Diligence LLC, c2018. Available from: http://www. blog.mediligence.com/2013/01/29/wound-prevalence-and-woundmanagement-2012-2020. [Last cited on 2016 Sep 09].

5. Dhivya S, Padma VV, Santhini E. Wound dressings: A review. BioMedicine 2015;5:24-8.

6. Bennett-Marsdem M. How to select a wound dressing. Clin Pharm 2010;2:363-5.

7. Health Care Article. Global Wound Dressings Market: Driven by Rising Healthcare Expenditure, Suppressed by Unfavorable Reimbursement Scenario. Transparency Market Research c2015. Available from: http:// www.transparencymarketresearch.com/articles.htm. [Last cited on 2017 Jan 11].

8. Dorai AA. Wound care with traditional, complementary and alternative medicine. Indian J Plast Surg 2012;45:418-4.

9. Vyas KS, Vasconez HC. Wound healing: Biologics, skin substitutes, biomembranes and scaffolds. Healthcare 2014;2:356-400.

10. Wound Care Resources. A Caring Approach to Wound Healing: Wound Dressing Categories. Yorkville: Wound Care Resources 4, Newbern, Highway P.O Box. 155. Available from: http://www. woundcareresources.net/education.html\#antimicrobial. [Last cited on 2016 Nov 01]

11. Sarabahi S. Recent advances in topical wound care. Indian J Plast Surg 2012;45:379.

12. Markets and Markets, Press Release. Wound Care Market Worth 22.01 Billion USD by 2022. Markets and Markets Research Private Limited c2009-2018. 2016 May. Available from: http://www. marketsandmarkets.com/Market-Reports/wound-care-market-371. html. [Last cited on $2017 \mathrm{Feb} 03$ ].

13. Marker Report Research Search Engine. Wound Dressings MarketGlobal Industry Analysis, Size, Share, Growth, Trends and Forecast, 2014-2020. Global News Wirec 2018, 2016. Available from https:// www.globenewswire.com/news-release/2016/09/22/873876/0/en/ Wound-Dressings-Market-Global-Industry-Analysis-Size-ShareGrowth-Trends-and-Forecast-2014-2020.html. [Last cited on 2016 Feb 23].

14. Snyder DL, Sullivan N, Schoelles KM. Skin Substitutes for Treating Chronic Wounds. Rockville (MD): Agency for Healthcare Research and Quality (US); 2012. 
15. Buan J, Carson A, Gelfman D, Inventors; Kalypto Medical Inc, Assignee. Negative pressure wound therapy device. United States patent US No. 9, 579, 431. 2017 Feb 28.

16. Seetharaman S, Natesan S, Stowers RS, Mullens C, Baer DG, Suggs LJ, et al. A PEGylated fibrin-based wound dressing with antimicrobial and angiogenic activity. Acta Biomater 2011;7:2787-96.

17. Bjork JW, Halverson KJ, Young AJ, Moeller SJ, Inventors; $3 \mathrm{M}$ Innovative Properties Co, Assignee. Fibrin-Coated Wound Dressing. United States Patent Application US No. 14/899,608. 2016 May 26.

18. Kloth LC. Electrical stimulation technologies for wound healing. Adv Wound Care 2014;3:81-90.

19. Khattak AZ, Ross R, Ngo T, Shoemaker CT. A randomized controlled evaluation of absorption of silver with the use of silver alginate (Algidex) patches in very low birth weight (VLBW) infants with central lines. AM J Perinatol 2010; 30:337.

20. Ousey K, Roberts C, Leaper D. Silver-containing dressings. In Wound Healing Biomaterials. UK: Cardiff University; 2016. p. 403-37.

21. Guilbaud. European comparative clinical study of Inerpan: A new wound dressing in treatment of partial skin thickness burns. J Burns 1992;18:419-22.

22. Molan PC. The evidence and the rationale for the use of honey as wound dressing. Wound Pract Rese 2011;19:204-20.

23. Paulsrud KS, Boberg JS. FDA Approval Regulations: Truth, Myths, and Misconceptions Chapter 58:315-7. Available from: http://www. podiatryinstitute.com/pdfs/Update_2010/2010_58.pdf. [Last cited on 2016 Feb 03]

24. Nadendla RR, Konuri DC, Prabhahar E. Desu BS. Comparison of medical device approval process in regulated countries, associates of regulated countries and emerging countries. Int J Adv Pharm Sci 2014;6:254654.

25. U.S. Food and Drug Administration. Overview of Medical Device Regulation, United States 2018 March. Available from: https://www. fda.gov/MedicalDevices/DeviceRegulationandGuidance/Overview/ default.htm. [Last cited on 2014 Jul 07].

26. Venkatesh MP, Bandla DT. Regulatory assessment of premarket approval of medical devices in US and EU. Int $\mathrm{J}$ Pharm Clin Res 2017:9:281-5

27. Lamph S. Regulation of medical devices outside the European Union. J R Soc Med 2012;105:12-21.

28. The Law Library of Congress, Global Legal Research Center. Approval of Medical Devices. Available from: https://www.loc.gov/law/help/ medical-devices/approval-of-medical-devices.pdf. [Last cited on 2016 Sep 05].

29. Deyo RA. Gaps, tensions, and conflicts in the FDA approval process: Implications for clinical practice. J Am Board Fam Pract 2004; 17:142-9.

30. US Food and Drug Administration Medical Device Exemptions (510k) and GMP Requirements. Available from: https://www.accessdata.fda. gov/scripts/cdrh/cfdocs/cfpcd/315.cfm?GMPPart=878. [Last cited on 2018 Jan 11].

31. Zaulyanov L, Kirsner RS. A review of a bi-layered living cell treatment

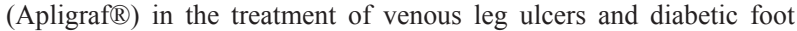
ulcers. Clin Interv Aging 2007;2:93.

32. French-Mowat E, Burnett J. How are medical devices regulated in the European Union. J R Soc Med 2012;105:22-8.

33. EUR-Lex. Access to European Union Law. Official Journal. Regulation of the European Parliament and of the Council on Medical Devices, and Amending Directive 2001/83/EC, Regulation (EC) No 178/2002 and Regulation (EC) No 1223/2009. Available from https://www.eurlex.europa.eu/legal-content/EN/TXT/?uri=CELEX:32017R0745. [Last cited on 2016 Jan 11].

34. European Commission. Active Implantable Medical Device. Council of the European Communities. Council Directive of $20^{\text {th }}$ June 1990 on the Approximation of the Laws of the Member States Relating to Active Implantable Medical Devices. 90/385/EEC 2007. Available from: https://www.ec.europa.eu/growth/single-market/european-standards/ harmonised-standards/implantable-medical-devices_en. [Last cited on 2016 Mar 03].

35. European Commission. European Standards. Council of the European Communities. Council Directive of $14^{\text {th }}$ June 1993 Concerning Medical Devices. 93/42/EEC. 2007. Available from: https://www.ec.europa. eu/growth/single-market/european-standards/harmonised-standards/ medical-devices_en. [Last cited on 2017 Apr 11].

36. European Commission. Council of the European Communities. Council Directive of $29^{\text {th }}$ June 1992 on General Product Safety 92/59/EEC. 1992. Available from: https://www.ec.europa.eu/growth/single-market/ european-standards/harmonised-standards/medical-devices en. [Last cited on 2017 Apr 11]

37. European Commission European Parliament and the Council of the European Union. Directive of the European Parliament and of the Council of $15^{\text {th }}$ December 2004 on the Approximation of the Laws of the Member States Relating to Electromagnetic Compatibility and Repealing Directive 89/336/EEC. 2004/108/EC; 2004. Available from https://www.ec.europa.eu/growth/single-market/european-standards/ harmonised-standards/implantable-medical-devices_en. [Last cited on 2017 Mar 17].

38. Ministry of Health, Labor and Welfare Japan: Pharmaceutical and Medical Device Agency. Overview of Medical Device Designation System. Available from: http://www.pmda.go.jp/english/index.html. [Last cited on 2017 Aug 23].

39. Health Canada. Guidance Document: How to Complete the Application for a New Medical Device. 2015. Available from: https://www. emergogroup.com/sites/default/files/guidance_how_to_complete_the application_for_a_new_medical_device_licence.pdf. $\overline{\text { [Last }}$ cited on 2017 Jun $1 \overline{2}$ ].

40. Canada. Medical Device Regulations SOR/98-282; 2017. Available from: http://www.laws-lois.justice.gc.ca/eng/regulations/sor-98-282. [Last cited on 2018 Jan 03].

41. Government of Canada. Health Canada: Management of Applications for Medical Device Licenses and Investigational Testing Authorizations. Available from: https://www.canada.ca/en/health-canada/services/ drugs-health-products/medical-devices/application-information/ policies/management-applications-medical-device-licencesinvestigational-authorizations.html. [Last cited on 2017 Nov 03].

42. Australian Regulatory Guidelines for Medical Devices (ARGMD). Available from: https://www.tga.gov.au/publication/australianregulatory-guidelines-medical-devices-argmd. [Last cited on 2015 May 06].

43. Australian Government, Department of Health. Therapeutic Goods Administration. The Regulation of Medical Device. Available from: https://www.tga.gov.au/behind-news/regulation-medical-devices. [Last cited on 2017 Oct 13]

44. TGA, Australian Medical Devices Guidelines, An Overview of the New Medical Devices Regulatory System, Guidance Document Number 1, Version 1.6, Published 23/05/2009. Printed 26/11/2014. Available from: https://www.tga.gov.au/sites/default/files/devices-argmd-01.pdf.

45. TGA, Australian Regulatory Guidelines for Medical Devices (ARGMD): Part 1 -Introduction 18 (version 1.1, May 2011). Available from: https://www.tga.gov.au/sites/default/files/devices-argmd-01. pdf.

46. Machado AF, Hochman B, Tacani PM, Liebano RE, Ferreira LM. Medical devices registration by ANVISA (Agência Nacional de Vigilância Sanitária). Clinics 2011;66:1095-6.

47. EMERGO. Medical Device Registration and Approval in Brazil. Available from Available from: https:/www.emergobyul.com/services/ brazil/anvisa-registration-brazil. [Last cited on 2018 May 12].

48. Medical Device Approval in Brazil: A Review and Update. Available from: Ble https:/www.2.frost.com/files/5314/2200/6768/Medical.pdf. [Last cited on 2018 May 12]

49. A Guide for Importing Medical Device in to Brazil. Available from: https:/www.nist.gov/sites/default/files/documents/2017/05/31/bra medical devices guide.pdf.

50. China Food and Drug Administration. Rules for Classification OF Medical Devices. Available from: http://eng.sfda.gov.cn/WS03/ CL0768/144302 html. [Last cited on 2018 Feb 11].

51. EUSME. Guideline Medical Device Registration c2011EUSMEcenter. Available from: http://www.ccilc.pt/wp-content/uploads/2017/07/ registo de dispositivos medicos en eusmecenter.pdf. [Last cited on 2017 May 07].

52. Health Science Authority. Singapore Medical Device Register. Available from: http://www.hsa.gov.sg/content/hsa/en/Health Products_Regulation/MEDICS_e-Services/Singapore_Medical_ Device Register smdr MEDICS. $\bar{h}$ tm. [Last cited on $2015 \bar{A}$ pr 03].

53. Health Science Authority Regulatory Guidelines. http://www.hsa.gov. sg/content/hsa/en/Health_Products_Regulation/Medical_Devices/ Overview/Guidances for Medical Device Registration.html. [Last cited on 2015 Aug 09].

54. Health Science Authority. Availabl;e from: http://www.hsa.gov.sg/ content/dam/HSA/HPRG/Manufacturing Importation Distribution/ Guidance\%20documents\%20for\%20Industry/GUIDE-MQA-026-001. pdf2015. [Last cited on 2015 May 03].

55. Health Science Authority GN-13-R1.1 Guidance on the Risk Classification of General Medical Devices. Available from: http:// www.hsa.gov.sg/content/dam/HSA/HPRG/Medical Devices/ 
Overview Framework Policies/Guidances for Medical Device Registration/GN-13-R1.1\%20Guidance $\% 20$ on $\% 20$ th $\% 20$ Risk $\% 20$ Classification $\% 20$ of $\% 20$ General $\% 20$ Medical $\% 20$ Devices.pdf.

56. Health Science Authority: GN-15-R6.1 Guidance on Medical Device Product Registration. Available from: http://www.hsapub.dynawebsite. com/content/hsa/en/Health_Products_Regulation/Medical_Devices/ Overview/Guidances_for_Medical_Device_Registration.html. [Last cited on 2016 Jan 07].

57. Health Science Authority: GN-16-R1.1 Guidance on Essential Principles for Safety and Performance of Medical Devices. Available from: http://www.hsapub.dynawebsite.com/content/hsa/en/Health Products Regulation/Medical Devices/Overview/Guidances for Medical_Device_Registration.html. [Last cited on 2014 Dec 05]

58. Health Science Authority, Regulatory guidance GN-22-R6.1 Guidance for Dealers on Class a Medical Devices Exempted from Product Registration. Available from: http://www.hsa.gov.sg/content/dam/HSA/ HPRG/Medical Devices/Overview Framework Policies/Guidances for Medical Device Registration/GN-22\%20R6.3\%20Guidance $\% 20$ for $\% 20$ Dealers $\% 20$ on $\% 20$ Class $\% 20$ A $\% 20$ Medical $\% 20$ Devices $\% 20$ Exempted $\% 20$ from $\% 20$ Product $\% 20$ Registration(17Nov-pub).pdf.

59. Health Science Authority, Fees and Charges Available from: http:// www.hsa.gov.sg/content/hsa/en/Health_Products_Regulation/ Medical Devices/Application Registration/Fees and Charges.html.

60. Singapore Government, Medical Device. Product registration and applicable evaluation fees for medical devices. Available from: http://www.hsa.gov.sg/content/hsa/en/Health Products Regulation/ Medical_Devices/Application_Registration/Target_Processing_ Timelines.html.

61. Pacific Bridge Medical, Medical Device Registration in Malaysia. Available from: https://www.pacificbridgemedical.com/regulatoryservices/medical-device/product-registration/malaysia/.

62. EMERGO. Medical Device Registration and Approval in Malaysia. EMERGO c2018. Available from: https://www.emergobyul.com/ services/malaysia/malaysia-registration. [Last cited on 2016 Feb 23].

63. Medical Device Regulatory System in Malaysia; 2013. Available from: http://www.mida.gov.my/env3/uploads/events/B2B2013/3-MDA.pdf. [Last cited on 2015 Aug 12].

64. Laws of Malaysia Act 737, Medical Device Act 2012. Available from: http://www.federalgazette.agc.gov.my/outputaktap/20120209 737 BI_JW001759\%20Act $\% 20737 \% 20(\mathrm{BI})$.pdf. [Last cited on $20 \overline{1} 5$ Jan 11].

65. Medical device Authority, Ministry of Health Malaysia; c2008-2015. Available from: http://www.mdb.gov.my/mdb/index.php?option=com content\&task=view\&id=184\&Itemid=50. [Last cited on 2015 Jun 03].

66. LNEG MED Registering Medical Device in Mexico News. Available from: https://www.lne-america.com/library/news/registering-medicaldevices-in-mexico. [Last cited on 2015 May 04].

67. Food Law Justice, Overview of Medical Device Approval in Mexico. Available from: http:/www.foodct.com/2011/12/12/overview-ofmedical-device-approval-in-mexico-cofepris-certification/. [Last cited on 2015 May 03].
68. Ministry of Health and Family Welfare. India Medical Device Rules, 2017. The Gazete of India: Extraordinary Part II-sec 3(i). Available from: http://www.cdsco.nic.in/writereaddata/Draft_Medical\%20 Devices \%20Rules\%202016.pdf. [Last cited on 2017 Nov 15].

69. Yadav V, Kumar D, Mathewson N. A new regulatory paradigm for medical device in India. Regulatory Focus Nov; 2017; c2017. Regulatory Affairs Professional Society. Available from: http://www. file://C:/Users/user1/Downloads/2017\%20Nov\%20Regulatory $\% 20$ Focus $\% 20$ New $\% 20$ regulatory $\% 20$ paradigm $\% 20$ India $\% 20$ Yadav $\% 20$ Kumar\%20Mathewson.pdf. [Last cited on 2018 Apr 10].

70. Medicsense The Israeli Medical Device Industry Continues Intense Growth. Available from: https://www.medicsense.com/6-business/incountry-israeli-registration-holder-irh/. [Last cited on 2018 Jan 11].

71. Licensale.com, Online Global Meditech Registration. Israel Medical Device Registration. Available from: http://www.arazygroup.com/ services/licensale/regions/israel. [Last cited on $2015 \mathrm{Jul} 17$ ]

72. RUSTANDARD. Product Certification in CIS, Medical Device Registration in Russia-Medical Device Registration Certificate. Rustandard Ltd. - Rustaveli Str. 14 Bldg 6, Office 31 - 115191 Moscow, Russia c2007-2018. Available from: http://www.rustandard. $\mathrm{com} / \mathrm{en} / \mathrm{medical}-d e v i c e-r e g i s t r a t i o n-i n-r u s s i a . h t m l$ [Last accessed on 2015 Jul 07]; [Last cited on 2017 Apr 21].

73. Ministry of Healthcare of the Russian Federation. Russia, New Rules Governing Registration. Available from: https://www.tuv-sud.com/ home-com/resource-centre/publications/e-ssentials-newsletter/mhs-essentials/e-ssentials-22013/russia-new-rules-governing-registration. [Last cited on 2017 Jul 07]

74. EMERGO GROUP. The Medical Device Approval Procedure in Russian Federation. Available from: https://www.emergobyul.com/ sites/default/files/file/emergo-group-russia-webinar.pdf?action. [Last cited on 2017 Jul 16].

75. Kavanagh S, de Jong A. Care of burn patients in the hospital. Burns 2004;30:A2-6.

76. Dodson BP, Levine AD. Challenges in the translation and commercialization of cell therapies. BMC Biotechnol 2015;15:70.

77. United States. Department of Health and Human Services. Guidance for Industry Chronic Cutaneous Ulcer and Burn Wounds Developing Products for Treatment. Available from: https://www. fda.gov/downloads/drugs/guidances/ucm071324.pdf. [Last cited on 2017 Feb 03].

78. Bairy KL, Abhinav R, Satyam SM. Evaluation of burn wound healing activity of topical regular insulin in non-diabetic and streptozocininduced diabetic rats. Int J PharmPharm Sci 2014;6:127-30.

79. Ilango K, Yoganandam GP, Usha K, Priyanga KS, Ilansezhiyan M, Kalaiarasi V. Evaluation of wound healing activity of hexane and methanolic extract of fruit plum of Momordica balsamina (Linn.) in Albino Rats. Int J Pharm Pharm Sci 2010;2:88-92.

80. Sullivan N, Snyder DL, Tipton K, Uhl S, Schoelles KM. Negative Pressure Wound Therapy Devices. Rockville (MD): Agency for Healthcare Research and Quality (US); 2009. Available from: http:// www.europepmc.org/abstract/med/25392896. 